\title{
Stable isotope and multi-analytical investigation of Monte da Cegonha: A Late Antiquity population in southern Portugal
}

\author{
Patrícia Saragoça a , Anne-France Maurer ${ }^{\text {a,* }}$, Lucija Šoberl a , Maria da Conceição Lopes ${ }^{\text {b,c }}$, Rafael Alfenim b,d, \\ Inês Leandro ${ }^{\text {e }}$, Cláudia Umbelino ${ }^{\text {e,f }}$, Teresa Fernandes ${ }^{\text {e,g }}$, Maria João Valente ${ }^{\text {b,h }}$, Sara Ribeiro ${ }^{\mathrm{i}}$, \\ José Francisco Santos ${ }^{\mathrm{i}}$, Ana Isabel Janeiro ${ }^{\mathrm{j}}$, Cristina Dias Barrocas ${ }^{\mathrm{a}, \mathrm{k}, *}$ \\ a HERCULES Laboratory, University of Évora, Largo Marquês de Marialva 8, 7000-809 Évora, Portugal \\ ${ }^{\mathrm{b}}$ Research Center in Archaeology, Arts and Heritage Sciences, University of Coimbra, Palácio de Sub-Ripas, 3000-395 Coimbra, Portugal \\ c Department of History, Archaeology and Arts, Faculty of Arts and Humanities, University of Coimbra, Largo da Porta Férrea, 3004-530 Coimbra, Portugal \\ ${ }^{d}$ Regional Directorate of Culture of Alentejo, Rua de Burgos 5, 7000-863 Évora, Portugal \\ e Research Centre for Anthropology and Health (CIAS), University of Coimbra, Apartado 3046, 3001-401 Coimbra, Portugal \\ ${ }^{\mathrm{f}}$ Department of Life Sciences, Faculty of Sciences and Technology, University of Coimbra, Calçada Martim de Freitas, 3000-456 Coimbra, Portugal \\ g School of Technology Sciences, Department of Biology, University of Évora, Apartado 94, 7002-554 Évora, Portugal \\ ${ }^{\text {h }}$ Faculty of Human and Social Sciences, University of Algarve, Campus de Gambelas, 8005-139 Faro, Portugal \\ ${ }^{i}$ Geobiotec, Department of Geosciences, University of Aveiro, Campus de Santiago, 3810-193 Aveiro, Portugal \\ ${ }^{\mathrm{j}}$ Institute Dom Luiz, Faculty of Sciences, University of Lisbon, 1749-016 Lisboa, Portugal \\ k School of Technology Sciences, Department of Chemistry, University of Évora, Rua Romão Ramalho 59, 7000-671 Évora, Portugal
}

\section{A R T I C L E I N F O}

\section{Article history:}

Received 7 March 2016

Received in revised form 20 June 2016

Accepted 7 July 2016

Available online 21 July 2016

\section{Keywords:}

Diet

Diagenesis

Collagen

Apatite

Mobility

Late Antiquity

Portugal

\begin{abstract}
A B S T R A C T
This study presents for the first time the diet of a Late Antiquity population in southern Portugal (Civitas of Pax Julia), from the Roman villa of Monte da Cegonha (predominantly 7th century CE). Stable isotope analysis $\left(\delta^{13} \mathrm{C}, \delta^{15} \mathrm{~N}, \delta^{18} \mathrm{O},{ }^{87} \mathrm{Sr} /{ }^{86} \mathrm{Sr}\right)$ of human and faunal bone collagen and apatite was conducted in order to understand the influence of Roman subsistence strategies on the way of life of rural inhabitants of the area of Pax Julia and to explore their diet (types of ingested plants, amount of animal resources, terrestrial versus marine resources). $\mathrm{X}$-ray diffraction (XRD) and Fourier transform infra-red spectroscopy (FTIR) analyses were used to determine the degree of bone diagenesis and assess the reliability of the bone stable isotopic composition for palaeodietary reconstruction. Anthropological analysis revealed a cariogenic diet, rich in starchy food and carbohydrates, in at least in two individuals based on the frequency of dental caries. Collagen and apatite carbon isotopic analysis suggested that $C_{3}$ plants were the basis of the population's diet, complemented with some terrestrial meat and its byproducts as reflected by the observed bone collagen nitrogen isotopic composition. Moreover, whilst the fairly low apatite-collagen spacing recorded in some skeletons (at around 4\%) may have been due to freshwater organisms intake, the relatively low nitrogen values observed indicate that this consumption did not occur very often, unless in the form of fresh fish of low trophic level or fish sauces. There were no significant differences in isotopic values depending on gender or burial type.

Strontium and oxygen isotopic composition of bone apatite revealed a sedentary community, with the exception of a male individual who probably did not spend his childhood in Monte da Cegonha.
\end{abstract}

(c) 2016 Elsevier Ltd. All rights reserved.

\section{Introduction}

This study examines for the first time the way of life, and more specifically the diet, of a Late Antiquity population in southern Portugal (Civitas of Pax Julia), using the geochemical composition of human and faunal remains from the Roman villa of Monte da Cegonha.

\footnotetext{
* Corresponding authors at: HERCULES Laboratory, University of Évora, Largo Marquês de Marialva 8, 7000-809 Évora, Portugal.

E-mail addresses: annefrance.maurer@gmail.com (A.-F. Maurer),cmbd@uevora.pt (C.D. Barrocas).
}

Stable isotope analysis is based on the principle that human and animal body tissues reflect the isotopic composition of the food and water ingested (Britton et al., 2008; Budd et al., 2013; Keenleyside et al., 2009; Müldner and Richards, 2007). Measuring the carbon $\left(\delta^{13} \mathrm{C}_{\mathrm{co}}\right)$ and nitrogen $\left(\delta^{15} \mathrm{~N}\right)$ isotopic ratios of bone collagen is a well-established technique for reconstruction of ancient diets (Bogaard et al., 2007; Craig et al., 2009; Keenleyside et al., 2009). Carbon isotope values can be used to distinguish plants using the $\mathrm{C}_{3}$ and $\mathrm{C}_{4}$ photosynthetic pathways and the individuals consuming these plants (Budd et al., 2013; Chenery et al., 2010). They can also be used to differentiate terrestrial and aquatic food sources (Chenery et al., 2010; Müldner et al., 2011). Carbon 
isotopic ratios incorporated into bone collagen derive mainly from dietary proteins (Ambrose and Norr, 1993; Howland et al., 2003; Mays and Beavan, 2012). Bone apatite $\left(\delta^{13} \mathrm{C}_{\mathrm{apa}}\right)$ reflects the isotopic composition of the complete diet (proteins, carbohydrates and lipids) (Ambrose et al., 2003; Brown and Brown, 2011). Mays and Beavan (2012) suggested that the use of bone apatite in conjunction with bone collagen enables a more complete assessment of palaeodiet. Apatite-collagen spacing ( $\delta^{13} \mathrm{C}_{\text {apa-col }}$ Spacing) has been used to estimate the type and proportion of protein in the overall diet (Turner et al., 2012). Nitrogen isotope values are used to infer the position of an individual in the food chain (Keenleyside et al., 2009), based on increased $\delta^{15} \mathrm{~N}$ values (2$6 \%$; Hedges and Reynard, 2007) with each trophic level, and are useful for distinguishing meat-rich diets from plant-rich diets, as well as the consumption of marine and freshwater resources (Bocherens and Drucker, 2003; Hedges and Reynard, 2007).

Human mobility can also be investigated using strontium and oxygen isotopes. Enamel ${ }^{87} \mathrm{Sr} /{ }^{86} \mathrm{Sr}$ isotopic ratios reflect the ${ }^{87} \mathrm{Sr} /{ }^{86} \mathrm{Sr}$ ratios of the local geological region in which an individual grew up. After formation, there are no alterations of ${ }^{87} \mathrm{Sr} /{ }^{86} \mathrm{Sr}$ ratios in enamel during an individual's lifetime and, as such, a ${ }^{87} \mathrm{Sr} /{ }^{86} \mathrm{Sr}$ ratio different from that of the burial location suggests that the individual moved from their place of infancy (Bentley, 2006). Comparison between ${ }^{87} \mathrm{Sr} /{ }^{86} \mathrm{Sr}$ ratios in the teeth and bones of an individual also suggest later mobility, because bones are continuously remodelled during a lifetime and their ${ }^{87} \mathrm{Sr} /{ }^{86} \mathrm{Sr}$ values change if a person moves to a region with a different geological signature (Brown and Brown, 2011). Similar information can be obtained from oxygen isotopes. Oxygen isotopic ratios yielded by phosphates and carbonates of bone mineral (apatite) derive from dissolved oxygen that has been ingested with water and food (Longinelli, 1984) with an oxygen isotopic composition $\left(\delta^{18} \mathrm{O}\right)$ that is dependent on geoenvironmental factors, i.e. latitude, altitude and distance to the coast (Dansgaard, 1964). Therefore, $\delta^{18} \mathrm{O}$ recorded in skeletons can be used to identify individuals who had access to a different water supply than rest of the local population. However, the suitability of $\delta^{18} \mathrm{O}$ to this application is still debated because for example, food preparation and drinking fermented beverages can alter isotopic ratio (Brettell et al., 2012).

Furthermore, bone isotopic composition might be altered during burial by diagenesis. Diagenesis is a complex process that involves biological and physico-chemical post-mortem alterations of skeletal material directly exposed to soil environments during burial (Beasley et al., 2014; Hollund et al., 2013; Lebon et al., 2010; Maurer et al., 2011, 2014). Such processes that affect bone preservation can be caused by microbial attack, temperature, humidity, hydrology, $\mathrm{pH}$, and may lead to partial or complete degradation of organic matter (Beasley et al., 2014; Lebon et al., 2010). Diagenesis is also associated with uptake or exchange of ions (Wright and Schwarcz, 1996) and changes in the crystallinity of bone mineral (Berna et al., 2004). During recrystallization, bone mineral can incorporate or adsorb dissolved ionic species from groundwater into its crystal structure, but it is not inevitable that the original isotope composition is altered (Hollund et al., 2013; Lee-Thorp, 2008). Changes in crystallinity relevant to the evaluation of diagenesis can be measured by X-ray diffraction (XRD) and attenuated total reflection Fourier transform infrared spectroscopy (ATR-FTIR) (Beasley et al., 2014; Berna et al., 2004; Brown and Brown, 2011). FTIR also gives information about the composition and structure of the organic phase (Hollund et al., 2013; Lebon et al., 2010).

\section{The archaeological site investigated}

The Roman villa of Monte da Cegonha is located $13.5 \mathrm{~km}$ northeast of Beja (Alentejo region, southern Portugal) (Fig. 1). This villa was built in the first quarter of the 1st century $\mathrm{CE}$ and lasted, with successive modifications, until the 12 th century $\mathrm{CE}$. The soil and available water resources of this area facilitated agricultural and animal husbandry practices, and allowed the establishment of local populations through

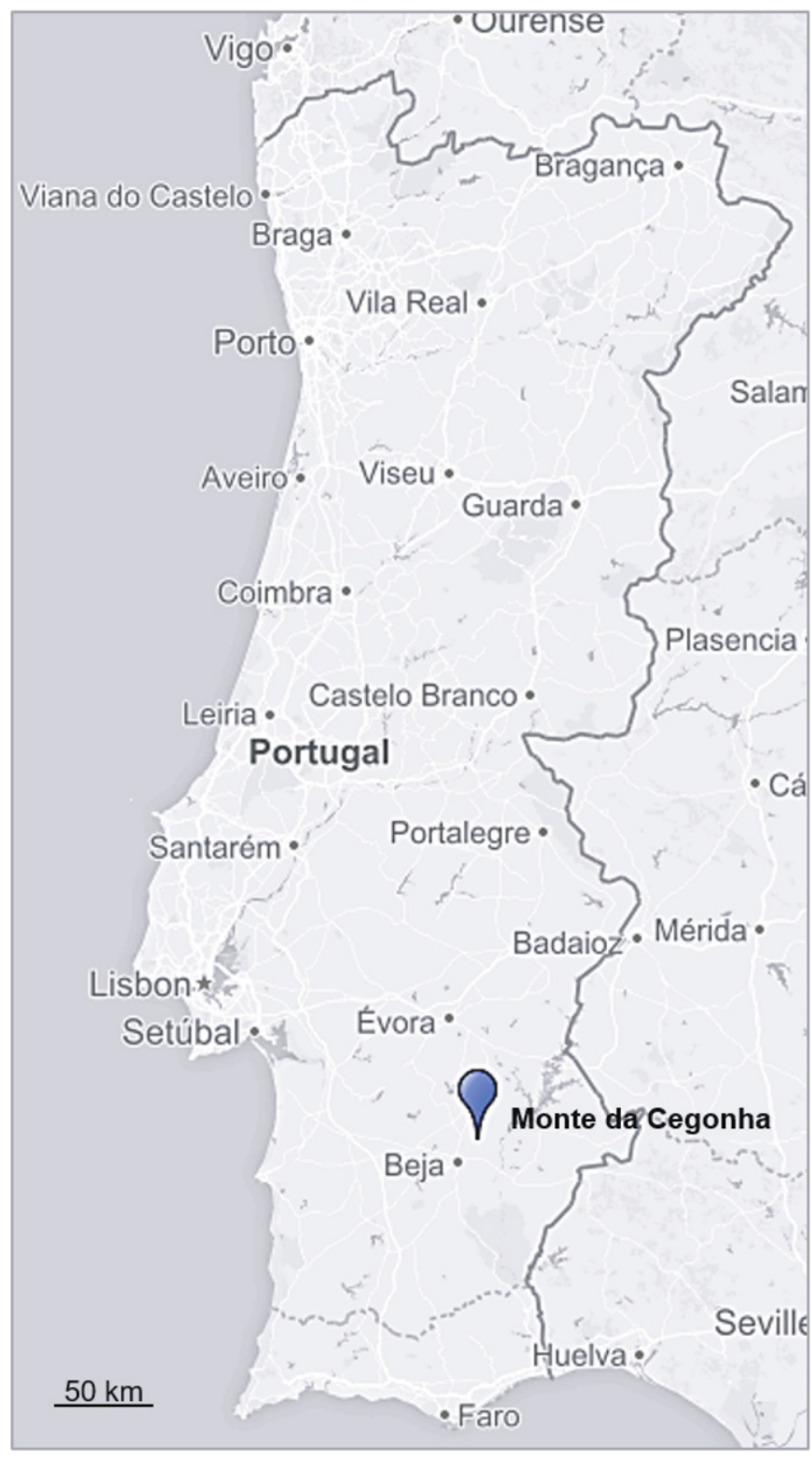

Fig. 1. Map showing the location of Monte da Cegonha.

time. The restructuring of the villa in the 4th century CE incorporated new buildings, including a Palaeochristian basilica. The basilica was used for interments until the end of the 6th century CE, although its funerary function was not the primary objective (Lopes and Alfenim, 1994). A total of 12 graves were uncovered, which were constructed with reused materials such as stone, brick and tiles, with the exception of one white marble sarcophagus (grave 2). All the graves were used and reused several times, as witnessed by the ossuaries accumulated at the foot of each tomb. The majority of primary burials found in articulation were inhumed in a decubitus dorsalis position with a West-East orientation. A minimum number of 25 individuals were retrieved for this study, although the total number of excavated individuals was higher (see Section 3.1 for more details). While nine graves were discovered inside the basilica, graves 7, 8 and 9 were buried outside the eastern and western church walls (Fig. 2). The council of Braga, which took place in $572 \mathrm{CE}$, where a ban on burials inside the temples was promulgated, provides terminus antequem for the use of this space as a necropolis and dates the new phase with establishment of a new screed, a new altar, a baptistery and a reliquary. This basilica was one of the oldest rural Palaeochristian churches in the Iberian Peninsula (Alfenim and 


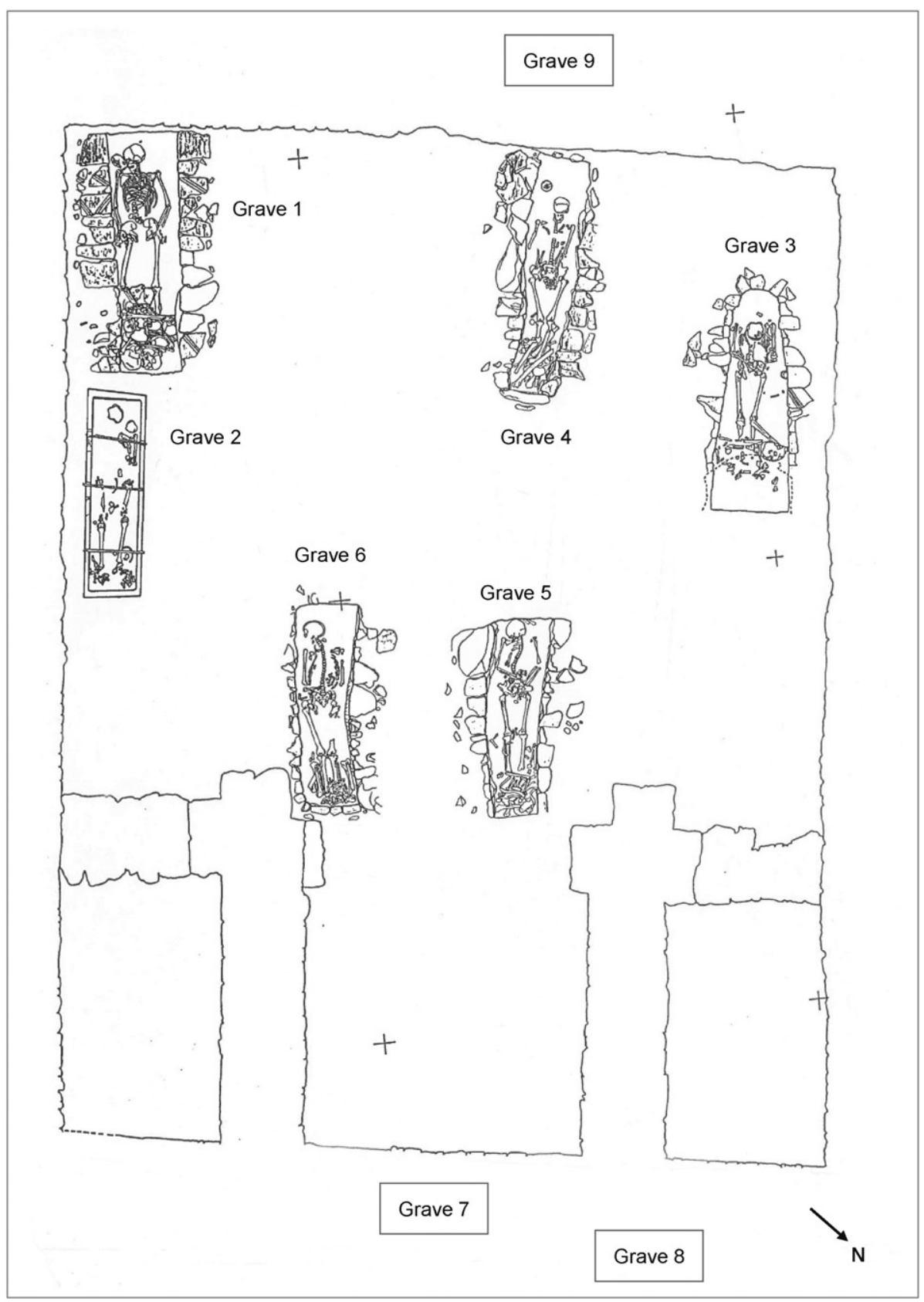

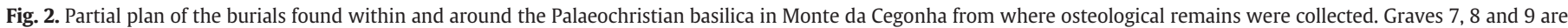
positioned approximately.

Lopes, 1992; Lopes and Alfenim, 1994). An unusual find was a reliquary found under the altar consisting of a gray marble box, possibly dated to the 6 th century CE. Silver fragments were found inside the reliquary that may have belonged to an ampulla, two ceramic medallions and two ceramic medals. The reliquary artefacts display similarities with materials found in Palestine and are likely to have been transported by a pilgrim (Alarcão et al., 1992; Alfenim and Lopes, 1992; Lopes and Alfenim, 1994). The basilica inside the villa has been renewed more than once during its existence, from the 4th century onwards, and the graves and ossuaries have been introduced in a second phase, thought to be finished by the end of the 6th century CE (Alfenim and Lopes, 1992) based on archaeological evidence and artefacts discovered at Monte da Cegonha. However, recent radiocarbon dating of human bones undertaken during this project, from three graves and one ossuary, revealed that the burials dated were mainly interred during a more recent period, by the mid of the 7th century CE, with a sample dating in the 8th-9th century CE (Table 1).

\section{Materials}

\subsection{Human samples}

Unfortunately not all osteological material from Monte da Cegonha was available for sampling and analysis. The best possible skeletal representation was selected from available material. Long and flat bones from 25 individuals buried in Monte da Cegonha and excavated from individual graves comprising skeletons in articulation and ossuary bones were sampled. These 25 individuals correspond to 5 individual skeletons and 20 ossuary burials. The inhumations sampled were adult individuals ( 4 females and 1 male), while the 20 ossuary burials included 5 
Table 1

Radiocarbon dates obtained for four human bones from Monte da Cegonha, performed at the Scottish Universities Environmental Research Centre, Glasgow, UK (SUERC). The calibrated age ranges were determined using the University of Oxford Radiocarbon Accelerator Unit calibration program (OxCal4).

\begin{tabular}{lllll}
\hline Grave & Sample & $\begin{array}{l}\text { Conventional } \\
\text { radiocarbon years } \\
(\mathrm{BP})\end{array}$ & $\begin{array}{l}\text { Calibrated radiocarbon } \\
\text { ages }(1 \sigma, \text { cal CE) }\end{array}$ & $\begin{array}{l}\text { Laboratory } \\
\text { code }\end{array}$ \\
\hline 2 & HMC 6 & $1363 \pm 28$ & $647-672$ & $\begin{array}{l}\text { SUERC-58539 } \\
(\text { GU36586) }\end{array}$ \\
5 & HMC 8 & $1228 \pm 31$ & $790-869$ & $\begin{array}{l}\text { SUERC-58544 } \\
(\text { GU36588) }\end{array}$ \\
& HMC 9 & $1373 \pm 31$ & $641-671$ & $\begin{array}{l}\text { SUERC-58540 } \\
\text { (GU36587) }\end{array}$ \\
7 & HMC & $1330 \pm 31$ & $654-690$ & $\begin{array}{l}\text { SUERC-58545 } \\
\text { (GU36589) }\end{array}$ \\
\hline
\end{tabular}

O - ossuary.

a Calibrated radiocarbon ages were obtained by using OxCal v4.2.4 and IntCal13.

children ( $<5$ years old) and 15 adults ( 1 female, 5 males, 2 probable males and 7 undetermined individuals). For the skeletons found in articulation more than one anatomical element was analysed for examining potential intra-skeletal geochemical differences (Maurer et al., 2011, 2014). In total 40 human samples were submitted for analysis and are listed in Table 2.

\subsection{Faunal samples}

In total, 21 faunal samples were collected from a range of contemporaneous animal remains excavated outside the basilica at various locations at Monte da Cegonha. Specimens were deliberately collected from different individuals, using similar bone portions or remains collected in different areas. The zooarchaeological analysis, including species identification, age, biometry and pathology, was carried out according to current standard techniques (e.g. Bull and Payne, 1982; Grant, 1982; Payne, 1973; Silver, 1969; von den Driesch, 1976; Zeder, 2006; Zeder and Lapham, 2010; Zeder and Pilaar, 2010). Animal samples included two wild species (rabbit, Oryctolagus cuniculus, and red deer, Cervus elaphus), at least two domestic species (cattle, Bos taurus, and ovicaprines: goat, Capra hircus, and perhaps sheep, Ovis aries) and swine (pig or wild boar, Sus sp.). Further information is listed in Table 3.

\section{Methods}

\subsection{Anthropological analysis}

All individuals were aged and sexed (Table 2) according to standard anthropological techniques (Beck, 1995; Bruzek, 2002; Ferembach et al., 1980; Lovejoy et al., 1985; MacLaughlin, 1990; Scheuer and Black, 2004; Silva, 1995; Wasterlain, 2000).

Stature was estimated using humerus maximal length and physiological length of the femur according to the regression formulae proposed by Mendonça (2000). For the evaluation of dental caries size and location, Lukacs (1989) and Moore and Corbett (1971) were used, while dental calculus was reported following Brothwell (1981). The analysis of dental wear was based on the Smith (1984) scoring system. Indicators of physiological stress, namely porotic hyperostosis, cribra orbitalia and dental enamel hypoplasias were macroscopically surveyed following the recommendations proposed by Beck (1995).

\subsection{Sampling}

Approximately 1-2 g of human and faunal bone samples were collected with a saw and external surfaces cleaned with a DREMEL $®$ drill to remove contaminating surface material and adhering soil.

\subsection{To test bone preservation}

\subsubsection{Infrared spectroscopy}

A total of 20 human and 7 faunal bone samples were examined using ATR-FTIR (Table 5). Samples were ground using an agate mortar and pestle to a fine powder. Infrared spectra were collected on a Bruker Alpha spectrometer coupled with a single-reflection diamond ATR module (100 scans with a spectral resolution of $4 \mathrm{~cm}^{-1}$, from 4000 to $375 \mathrm{~cm}^{-1}$ ). All spectra were acquired in absorbance mode and were recorded and analysed using OPUS/Mentor software (version 6.5). Peak heights at wavenumber 565, 603, 1030, 1035, 1415 and $1640 \mathrm{~cm}^{-1}$ were used for the calculation of the Infrared Splitting Factor (IRSF), relative carbonate content $(\mathrm{C} / \mathrm{P})$ and relative collagen content $(\mathrm{Am} / \mathrm{P})$. The sum of the absorbance values of the two phosphate peaks at wavenumbers $565\left(\nu 4 \mathrm{PO}_{4}\right)$ and $603 \mathrm{~cm}^{-1}\left(\nu 4 \mathrm{PO}_{4}\right)$ was then divided by the height of the valley between them to obtain the IRSF value, following the protocol described by Weiner and Bar-Yosef (1990). Relative carbonate content was measured by the peak heights at wavenumbers $1035\left(\nu 3 \mathrm{PO}_{4}\right)$ and $1415 \mathrm{~cm}^{-1}\left(\nu 3 \mathrm{CO}_{3}\right)$ (Wright and Schwarcz, 1996). Relative collagen content was measured by the intensity ratio of the amide I peak at $1640 \mathrm{~cm}^{-1}$ versus the phosphate peak at $1030 \mathrm{~cm}^{-1}$ (Trueman et al., 2008). All FTIR analyses were performed in the HERCULES Laboratory.

\subsubsection{X-ray diffraction analysis}

A total of 20 human and 6 faunal bone samples were analysed using XRD (Table 5). Samples were ground using an agate mortar and pestle to a fine powder. X-ray diffraction data was obtained with $\mathrm{Cu} \mathrm{K \alpha}$ radiation on a Bruker AXS D8 Advance with a DAVINCI design diffractometer, equipped with a Göbel mirror assembly and a LynxEye 1D detector ( $2 \theta$ angular range of $20.000^{\circ}-40.184^{\circ}$, step size of $0.020^{\circ}$ and a step time of $6 \mathrm{~s})$. The peaks corresponding to reflections [211], [112], [300] and [202] were measured to calculate the crystallinity of the samples, Crystallinity Index (CI) (Person et al., 1995). All the X-ray diffractograms were checked for the presence of other minerals, such as quartz or calcite. All XRD analyses were performed in the HERCULES Laboratory.

\subsection{Bone collagen extraction and analysis}

Collagen was extracted using the method of Longin (1971) with some modification (Britton et al., 2008; Knipper et al., 2012; Salesse et al., 2014). Between 300 and $500 \mathrm{mg}$ of bone sample was demineralized in $10 \mathrm{ml} 0.5 \mathrm{M} \mathrm{HCl}$ at $4{ }^{\circ} \mathrm{C}$ for approximately 14 days, with regular vortex and an acid change after one week. After demineralization, the samples were rinsed to neutrality with ultrapure water and soaked in $0.125 \mathrm{M}$ $\mathrm{NaOH}$ for $20 \mathrm{~h}$ at room temperature to oxidize fulvic and humic acids. The samples were rinsed again to neutrality with ultrapure water and gelatinized in $0.01 \mathrm{M} \mathrm{HCl}$ at $70{ }^{\circ} \mathrm{C}$ for $48 \mathrm{~h}$. The liquid fraction containing the gelatinized protein was filtered using Ezee-Filter ${ }^{\mathrm{TM}}$ separators (Elkay Laboratory Products) to remove impurities. The solubilized collagen was frozen, lyophilized for $48 \mathrm{~h}$ and analysed.

Extracted and freeze-dried collagen samples were weighed into tin capsules (between 0.7 and $1.2 \mathrm{mg}$ ) and combusted into $\mathrm{CO}_{2}$ and $\mathrm{N}_{2}$ in an elemental analyser (EA) with oxygen (Flash 2000 HT, Thermo Fisher Scientific, Bremen, Germany) using pure helium as carrier gas. Isotopic ratios of carbon and nitrogen were obtained on a Delta V Advantage isotope ratio mass spectrometer (Thermo Fisher Scientific, Bremen, Germany) coupled to the EA via ConFlo IV interface (Thermo Fisher Scientific, Bremen, Germany).

The raw data were normalized by two-point calibrations using international reference materials, such as IAEA-CH-6 (sucrose, - $10.449 \%$ ) and IAEA-CH-7 (polyethylene, - 32.151\%) for carbon and IAEA-N-1 (ammonium sulphate, $+0.4 \%$ ) and IAEA-N-2 (ammonium sulphate, $+20.3 \%$ ) for nitrogen isotopic composition. Measurement errors were less than $\pm 0.1 \%$ or carbon and $\pm 0.2 \%$ ofor nitrogen. The $\delta^{13} \mathrm{C}$ and $\delta{ }^{15} \mathrm{~N}$ values are expressed in per mill and relative to VPDB and 
Table 2

Information pertaining to individual archaeological contexts, estimated age-at-death, sex, skeletal element analysed and pathologies of studied individuals from Monte da Cegonha.

\begin{tabular}{|c|c|c|c|c|c|}
\hline Grave & Age & Sex & Sample & $\begin{array}{l}\text { Skeletal } \\
\text { element }\end{array}$ & Pathologies \\
\hline \multirow[t]{5}{*}{1} & Adult & Male & $\begin{array}{l}\text { HMC } 1 \\
(\mathrm{O})\end{array}$ & $\begin{array}{l}\text { Femur } \\
(\mathrm{R})\end{array}$ & - \\
\hline & Young adult & Female & $\begin{array}{l}\text { HMC } 2 \\
(\mathrm{O})\end{array}$ & $\begin{array}{l}\text { Femur } \\
(\mathrm{R})\end{array}$ & - \\
\hline & Non adult ( $\sim 5$ years) & Undetermined & $\begin{array}{l}\text { HMC } 3 \\
\text { (0) }\end{array}$ & $\begin{array}{l}\text { Femur } \\
(\mathrm{R})\end{array}$ & - \\
\hline & Non adult ( $\sim 3$ years $)$ & Undetermined & $\begin{array}{l}\text { HMC } 4 \\
(0)\end{array}$ & $\begin{array}{l}\text { Femur } \\
(\mathrm{R})\end{array}$ & - \\
\hline & Non adult ( 6 months) & Undetermined & $\begin{array}{l}\text { HMC } 5 \\
(\mathrm{O})\end{array}$ & $\begin{array}{l}\text { Femur } \\
(\mathrm{R})\end{array}$ & - \\
\hline \multirow[t]{4}{*}{2} & Young adult ( $<27$ years) & Female & HMC 6 & Femur (L) & - \\
\hline & & & HMC 26 & Sacrum & - \\
\hline & & & HMC 27 & $\operatorname{Rib}(\mathrm{L})$ & - \\
\hline & & & HMC 28 & Scapula & - \\
\hline \multirow[t]{4}{*}{4} & Young adult ( $<27$ years) & Female & HMC 7 & $\begin{array}{l}\text { Femur } \\
(\mathrm{R})\end{array}$ & $\begin{array}{l}\text { Cariogenic lesions (grade 1), dental calculus (grades 1-3), dental wear (grades 1-2) and } \\
\text { dental enamel hypoplasia }\end{array}$ \\
\hline & & & HMC 29 & $\begin{array}{l}\text { Humerus } \\
(\mathrm{R})\end{array}$ & \\
\hline & & & HMC 30 & Ulna & \\
\hline & & & HMC 31 & Tibia (L) & \\
\hline \multirow[t]{6}{*}{5} & Adult ( $~ 40$ years) & Female & HMC 8 & $\begin{array}{l}\text { Humerus } \\
\text { (L) }\end{array}$ & $\begin{array}{l}\text { Cariogenic lesions (grades 1-3), dental calculus (grades 1-2), dental wear (grades 3-4) } \\
\text { and dental enamel hypoplasia }\end{array}$ \\
\hline & & & HMC 32 & Cranial & \\
\hline & & & HMC 33 & $\begin{array}{l}\text { Humerus } \\
\text { (L) }\end{array}$ & \\
\hline & & & HMC 34 & Ulna & \\
\hline & Adult & Undetermined & $\begin{array}{l}\text { HMC } 9 \\
(0)\end{array}$ & $\begin{array}{l}\text { Femur } \\
(\mathrm{R})\end{array}$ & - \\
\hline & & Undetermined & $\begin{array}{l}\text { HMC } 10 \\
(0)\end{array}$ & $\begin{array}{l}\text { Femur } \\
(\mathrm{R})\end{array}$ & - \\
\hline \multirow[t]{5}{*}{6} & Adult & Male & HMC 11 & Femur (L) & Dental calculus (grades 1-2), dental wear (grades 4-7) and dental enamel hypoplasia \\
\hline & & & HMC 35 & $\operatorname{Rib}(\mathrm{L})$ & \\
\hline & & & HMC 36 & Scapula & \\
\hline & & & HMC 37 & $\begin{array}{l}\text { Humerus } \\
\text { (R) }\end{array}$ & \\
\hline & Adult & Male & $\begin{array}{l}\text { HMC } 12 \\
(0)\end{array}$ & Femur (L) & - \\
\hline \multirow[t]{6}{*}{7} & Young adult ( $<23$ years) & Female & HMC 13 & Femur (L) & Dental calculus (grades 1-2), dental wear (grades 1-2) and dental enamel hypoplasia \\
\hline & & & HMC 38 & Cranial & \\
\hline & & & HMC 39 & Rib (R) & \\
\hline & & & HMC 40 & $\begin{array}{l}\text { Radius } \\
\text { (R) }\end{array}$ & \\
\hline & Young adult & Male & $\begin{array}{l}\text { HMC } 14 \\
(0)\end{array}$ & $\begin{array}{l}\text { Femur } \\
(\mathrm{R})\end{array}$ & - \\
\hline & Adult & Male? & $\begin{array}{l}\text { HMC } 15 \\
\text { (0) }\end{array}$ & $\begin{array}{l}\text { Femur } \\
(\mathrm{R})\end{array}$ & - \\
\hline \multirow[t]{5}{*}{8} & $\begin{array}{l}\text { Non adult ( } 38 \text { weeks in } \\
\text { uterus- } 1.5 \text { months) }\end{array}$ & Undetermined & $\begin{array}{l}\text { HMC } 16 \\
(0)\end{array}$ & $\begin{array}{l}\text { Humerus } \\
(\mathrm{R})\end{array}$ & - \\
\hline & Non adult ( 6 months-1 year) & Undetermined & $\begin{array}{l}\text { HMC } 17 \\
(\mathrm{O})\end{array}$ & $\begin{array}{l}\text { Humerus } \\
\text { (L) }\end{array}$ & - \\
\hline & Adult & Male? & $\begin{array}{l}\text { HMC } 18 \\
\text { (O) }\end{array}$ & Femur (L) & - \\
\hline & Adult & Undetermined & $\begin{array}{l}\text { HMC } 19 \\
(0)\end{array}$ & Femur (L) & - \\
\hline & Undetermined & Undetermined & $\begin{array}{l}\text { HMC } 20 \\
(0)\end{array}$ & Femur & - \\
\hline \multirow[t]{5}{*}{9} & Young adult & Male & $\begin{array}{l}\text { HMC } 21 \\
(0)\end{array}$ & Femur (L) & - \\
\hline & Adult & Male & $\begin{array}{l}\text { HMC } 22 \\
\text { (0) }\end{array}$ & Femur (L) & - \\
\hline & Adult & Undetermined & $\begin{array}{l}\text { HMC } 23 \\
(0)\end{array}$ & Femur (L) & - \\
\hline & Adult & Undetermined & $\begin{array}{l}\text { HMC } 24 \\
(\mathrm{O})\end{array}$ & Femur (L) & - \\
\hline & Adult & Undetermined & $\begin{array}{l}\text { HMC } 25 \\
(0)\end{array}$ & Femur (L) & - \\
\hline
\end{tabular}

L - left; R - right; O - ossuary.

AIR, with analytical precision of $0.1 \%$ and $0.2 \%$, respectively. A calibrated in-house standard (L-alanine, $\delta^{13} \mathrm{C}=-19.17 \%$; $\delta{ }^{15} \mathrm{~N}=+4.36 \%$ ) was measured at regular intervals throughout analytical sequences (every eight analyses) to check and correct for instrumental drift.
Samples were run at least in duplicates. The elemental (C\%, N\%) and isotopic composition of analysed collagen samples is reported in Table 6. All EA-IRMS analyses were performed in the HERCULES Laboratory. 
Table 3

Information on taxonomy, skeletal element analysed and age of faunal species studied from Monte da Cegonha. N.B. when possible the distinction between Ovis aries (sheep) and Capra hircus (goat) was made using the criteria of Zeder and Lapham (2010) and Zeder and Pilaar (2010).

\begin{tabular}{|c|c|c|c|c|}
\hline Taxonomy & Skeletal element & Age & Sample & Comments \\
\hline Cervus elaphus & Tibia & Adult & FMC 2 & - \\
\hline $\begin{array}{l}\text { Oryctolagus } \\
\text { cuniculus }\end{array}$ & Mandible & Adult & $\begin{array}{l}\text { FMC } \\
21\end{array}$ & - \\
\hline Capra hircus & Mandible & Adult & FMC 6 & - \\
\hline Capra hircus & Mandible & Adult & FMC 7 & - \\
\hline Capra hircus & Mandible & $\begin{array}{l}\text { Young } \\
\text { adult }\end{array}$ & FMC 9 & - \\
\hline Capra hircus & Mandible & Adult & $\begin{array}{l}\text { FMC } \\
14\end{array}$ & - \\
\hline Capra hircus & Mandible & Adult & $\begin{array}{l}\text { FMC } \\
15\end{array}$ & - \\
\hline Capra hircus & Mandible & Adult & $\begin{array}{l}\text { FMC } \\
20\end{array}$ & - \\
\hline $\begin{array}{l}\text { Ovis aries/Capra } \\
\text { hircus }\end{array}$ & Humerus & Adult & FMC 4 & $\begin{array}{l}\text { Probably Ovis } \\
\text { aries }\end{array}$ \\
\hline $\begin{array}{l}\text { Ovis aries/Capra } \\
\quad \text { hircus }\end{array}$ & Mandible & Adult & FMC 8 & - \\
\hline $\begin{array}{l}\text { Ovis aries/Capra } \\
\quad \text { hircus }\end{array}$ & Mandible & $\begin{array}{l}\text { Young } \\
\text { adult }\end{array}$ & $\begin{array}{l}\text { FMC } \\
10\end{array}$ & - \\
\hline $\begin{array}{l}\text { Ovis aries/Capra } \\
\quad \text { hircus }\end{array}$ & Tibia & Adult & $\begin{array}{l}\text { FMC } \\
11\end{array}$ & $\begin{array}{l}\text { Probably Ovis } \\
\text { aries }\end{array}$ \\
\hline $\begin{array}{l}\text { Ovis aries/Capra } \\
\quad \text { hircus }\end{array}$ & Pelvis & Adult & $\begin{array}{l}\text { FMC } \\
17\end{array}$ & - \\
\hline Bos taurus & $\begin{array}{l}\text { Proximal } \\
\text { phalanx }\end{array}$ & Adult & FMC 1 & - \\
\hline Bos taurus & Metacarpal & Adult & FMC 3 & - \\
\hline Bos taurus & Radius & Adult & FMC 5 & - \\
\hline Bos taurus & Astragalus & Adult & $\begin{array}{l}\text { FMC } \\
12\end{array}$ & - \\
\hline Bos taurus & Mandible & Adult & $\begin{array}{l}\text { FMC } \\
13\end{array}$ & - \\
\hline Bos taurus & Maxillary & Adult & $\begin{array}{l}\text { FMC } \\
16\end{array}$ & - \\
\hline Bos taurus & Astragalus & Juvenile & $\begin{array}{l}\text { FMC } \\
19\end{array}$ & - \\
\hline Sus sp. & Metacarpal IV & $\begin{array}{l}\text { Young } \\
\text { adult }\end{array}$ & $\begin{array}{l}\text { FMC } \\
18\end{array}$ & - \\
\hline
\end{tabular}

\subsection{Bone apatite extraction and analysis}

Apatite was extracted from the bone samples following the method of Koch et al. (1997) with modifications (Rand, 2011; Salesse et al., 2013). Bone samples were ground using an agate mortar and pestle and approximately $30 \mathrm{mg}$ of bone powder was soaked in $1.2 \mathrm{ml} 2.5 \%$ $\mathrm{NaOCl}$ solution at room temperature for $24 \mathrm{~h}$ to remove any organic matter. The samples were rinsed with ultrapure water and centrifuged five times to remove the $\mathrm{NaOCl}$. The remaining fraction was treated with $1.2 \mathrm{ml} 1 \mathrm{M} \mathrm{CH}_{3} \mathrm{COOH}$ buffered with $\mathrm{CH}_{3} \mathrm{COOLi}$ at room temperature for $24 \mathrm{~h}$ to eliminate exogenous and adsorbed carbonate. The samples were rinsed with ultrapure water and centrifuged five times for 5 min to remove the buffered acetic acid. The samples were then oven-dried at $40{ }^{\circ} \mathrm{C}$ for $24 \mathrm{~h}$ before being analysed at the Isotope Mass Spectrometry Service of the National Museum of Natural History (MNHN, Paris). Around $600 \mu \mathrm{g}$ of apatite powder were reacted with $100 \% \mathrm{H}_{3} \mathrm{PO}_{4}$ at $70{ }^{\circ} \mathrm{C}$ in a Kiel IV device connected to a Delta V Advantage (Thermo Scientific) isotope ratio mass spectrometer for measuring $\delta^{13} \mathrm{C}_{\mathrm{apa}}$ and $\delta^{18} \mathrm{O}_{\text {carb }}$ values.

The internal carbonate standard (Marble LM), normalized to the international standard NBS 19, was used for checking the accuracy of the measurements (theoretical $\delta^{13} \mathrm{C}$ and $\delta^{18} \mathrm{O}$ values of $2.13 \%$ and $-1.83 \%$, respectively) and to apply a correction to the samples varying from -0.01 to $0.01 \%$ for $\delta^{13} \mathrm{C}_{\text {apa }}$ and -0.16 to $-0.30 \%$ for $\delta^{18} \mathrm{O}_{\text {carb. }}$

Between 14 and 18 analyses of the standard Marble LM provided an analytical precision within each run, of 0.01 to $0.04 \%$ for $\delta^{13} \mathrm{C}$ and of 0.01 to $0.12 \%$ of $\delta^{18} \mathrm{O}$.

\subsection{Strontium isotope: sample preparation and analysis}

Strontium isotopic analyses were performed on human tooth enamel of four individuals (graves 4, 5, 6 and 7) and on two human bones (graves 5 and 6). Around $20 \mathrm{mg}$ of powder samples were collected using a drill diamond bit. All skeletal tissues were pre-treated with $1 \mathrm{M} \mathrm{Li}$ acetate-acetic acid. Bones were then ashed at $550^{\circ} / 12 \mathrm{~h}$ in acidcleaned ceramic crucibles.

In order to determine the local bioavailable ${ }^{87} \mathrm{Sr} /{ }^{86} \mathrm{Sr}$ signature of Monte da Cegonha site, two modern water and eight vegetation samples were collected from variable geological outcrops (Maurer et al., 2012), in the vicinity of Monte da Cegonha (Table 4), characterized during the field work that took place in October 2014. After collection, the plant leaves were cleaned with ultrapure water, dried in an oven at $50{ }^{\circ} \mathrm{C}$ and then ashed in a muffle furnace at $550^{\circ} / 12 \mathrm{~h}$ in acid-cleaned ceramic crucibles. Water samples were acidified with Suprapur ${ }^{\circ} \mathrm{HNO}_{3}$ (to get a final solution of $0.2 \% \mathrm{HNO}_{3}$ ) and filtered with $0.45 \mu \mathrm{m}$ Nylon membrane (VWR). Environmental samples and skeletal tissues were digested, $\mathrm{Sr}$ extracted and analysed at the Isotope Geology Laboratory of the University of Aveiro. All samples were digested using Suprapur ${ }^{\circledR}$ nitric acid (with the addition of $\mathrm{H}_{2} \mathrm{O}_{2}$ for plant samples) and evaporated to dryness. AG8 50W Bio-Rad resin was used for separating Sr from isobaric interferences, further loaded onto Ta filaments with $\mathrm{H}_{3} \mathrm{PO}_{4}$ and measured with a VG Sector 54 TIMS in dynamic mode. The standard reference material NIST SRM 987 was concomitantly measured and provided a value of $0.710278 \pm 14$ (conf. limit 95\%, N = 13). Strontium procedural blanks were $<500 \mathrm{pg} \mathrm{Sr}$.

\subsection{Statistical analyses}

Statistical analyses were performed using ANDAD (developed by Jorge de Sousa, Technical University of Lisbon, http://biomonitor.ist. utl.pt/ ajsousa/Andad.html [accessed 20 November 2015]) and PAST 3.10 for Windows. Results were investigated using principal component analysis (PCA) on ANDAD and non-parametric Mann-Whitney $U$ tests on PAST.

\section{Results}

\subsection{Anthropological analysis}

From the 25 individuals analysed, stature was estimated on eight individuals, four of them represented by skeletons in articulation and the remaining four only by femurs. The male average, $164.60 \pm 6.90 \mathrm{~cm}$ $(n=3)$ was obtained using the physiological length of the femur. For females using the physiological length of the femur, an average of $154.90 \pm 5.92 \mathrm{~cm}(\mathrm{n}=4)$ was achieved. The humerus maximal length of another female gave a stature of $154.70 \pm 7.70 \mathrm{~cm}$. These values are consistent with expected values for both sexes and they are compatible with those referred by Cardoso and Gomes (2009) for Portuguese populations of the same timeline.

Table 4

Geological substrate and or field observation at each sampling point for water and plant collected in the vicinity of Monte da Cegonha site.

\begin{tabular}{ll}
\hline Vegetation sample & Geological substrate/observation \\
\hline 1 plant & Metapelite \\
2 plant & Metapelite \\
3 plant & Weathered diorite \\
4 plant & Dioritic, variation of granites, no schists \\
5 plant & Amphibolite \\
6 water & Local stream \\
7 water & Ribeira do Freixo \\
7 plant & Adjacent to Ribeira do Freixo \\
8 plant & Metabasic outcrop \\
\hline
\end{tabular}


Only four individuals could be considered for the study of oral pathology, since the remaining one from grave 2 had no associated cranial or dental remains. From these, only two showed the presence of cariogenic lesions, inhumations in graves 4 and 5. Dental calculus was observed on all four individuals analysed (graves 4, 5, 6 and 7) and all of them displayed dental wear. The indicators of physiological stress were applied only to four individuals. Porotic hyperostosis and cribra orbitalia were not recorded. However, dental enamel hypoplasias (DEH) were detected in four analysed individuals. All of the oral pathologies and physiological stress indicators are presented in Table 2.

Table 5

Results of FTIR (IRSF, C/P and Am/P) and X-ray diffraction ( $\mathrm{CI}$ and secondary minerals present in bone porosity) analyses of 20 human bone samples ( 5 individual skeletons from graves 2-7 and 9 individuals from ossuaries) and 7 faunal bone samples.

\begin{tabular}{|c|c|c|c|c|c|c|c|}
\hline & \multirow[t]{2}{*}{ Grave } & \multirow[t]{2}{*}{ Sample } & \multicolumn{3}{|c|}{ ATR-FTIR } & \multicolumn{2}{|l|}{ XRD } \\
\hline & & & IRSF & $\mathrm{C} / \mathrm{P}$ & $\mathrm{Am} / \mathrm{P}$ & $\mathrm{CI}$ & Minerals \\
\hline \multirow[t]{21}{*}{ Skeletons } & \multirow[t]{3}{*}{2} & HMC 6 & 3.34 & 0.45 & 0.28 & 0.04 & Calcite \\
\hline & & HMC & 4.10 & 0.22 & 0.09 & 0.10 & - \\
\hline & & 27 & & & & & \\
\hline & \multirow[t]{3}{*}{4} & HMC 7 & 3.78 & 0.27 & 0.07 & 0.11 & Calcite \\
\hline & & HMC & 5.92 & 0.11 & 0.03 & 0.24 & Calcite \\
\hline & & 31 & & & & & \\
\hline & \multirow[t]{3}{*}{5} & HMC 8 & 4.05 & 0.21 & 0.08 & 0.14 & Calcite \\
\hline & & HMC & 5.33 & 0.10 & 0.02 & 0.32 & Calcite \\
\hline & & 32 & & & & & \\
\hline & \multirow[t]{4}{*}{6} & HMC & 5.20 & 0.10 & 0.02 & 0.30 & Calcite \\
\hline & & 11 & & & & & \\
\hline & & HMC & 4.31 & 0.21 & 0.08 & 0.27 & Quartz \\
\hline & & 36 & & & & & \\
\hline & \multirow[t]{6}{*}{7} & HMC & 4.09 & 0.21 & 0.10 & 0.19 & - \\
\hline & & 13 & & & & & \\
\hline & & HMC & 4.04 & 0.16 & 0.06 & 0.28 & - \\
\hline & & 39 & & & & & \\
\hline & & HMC & 4.19 & 0.22 & 0.10 & 0.19 & - \\
\hline & & 40 & & & & & \\
\hline & \multirow{2}{*}{\multicolumn{2}{|c|}{ Average }} & $4.40 \pm$ & $0.21 \pm$ & $0.08 \pm$ & $0.20 \pm$ & - \\
\hline & & & 0.8 & 0.1 & 0.1 & 0.1 & \\
\hline \multirow[t]{17}{*}{ Ossuaries } & \multirow[t]{2}{*}{1} & HMC 2 & 4.69 & 0.12 & 0.02 & 0.41 & - \\
\hline & & HMC 3 & 4.17 & 0.19 & 0.02 & 0.31 & Calcite \\
\hline & \multirow[t]{3}{*}{5} & HMC 9 & 4.24 & 0.19 & 0.09 & 0.10 & Calcite \\
\hline & & HMC & 5.67 & 0.09 & 0.02 & 0.32 & Calcite \\
\hline & & 10 & & & & & \\
\hline & \multirow[t]{2}{*}{7} & HMC & 4.14 & 0.22 & 0.10 & 0.18 & - \\
\hline & & 14 & & & & & \\
\hline & \multirow[t]{4}{*}{8} & HMC & 4.05 & 0.18 & 0.04 & 0.35 & - \\
\hline & & 18 & & & & & \\
\hline & & HMC & 4.37 & 0.14 & 0.08 & 0.31 & - \\
\hline & & 20 & & & & & \\
\hline & \multirow[t]{4}{*}{9} & HMC & 4.56 & 0.13 & 0.02 & 0.33 & - \\
\hline & & 24 & & & & & \\
\hline & & HMC & 4.30 & 0.17 & 0.16 & 0.23 & Calcite \\
\hline & & 25 & & & & & \\
\hline & \multirow{2}{*}{\multicolumn{2}{|c|}{ Average }} & $4.47 \pm$ & $0.16 \pm$ & $0.06 \pm$ & $0.28 \pm$ & - \\
\hline & & & 0.5 & 0.0 & 0.0 & 0.1 & \\
\hline \multirow[t]{13}{*}{ Fauna } & - & FMC 1 & 3.44 & 0.28 & 0.30 & 0.05 & Calcite, \\
\hline & - & FMC 2 & 3.75 & 0.21 & 0.07 & 0.24 & - \\
\hline & - & FMC 3 & 3.50 & 0.28 & 0.08 & 0.15 & - \\
\hline & - & FMC & 3.76 & 0.21 & 0.06 & 0.19 & - \\
\hline & & 13 & & & & & \\
\hline & - & FMC & 3.70 & 0.24 & 0.05 & 0.21 & Calcite \\
\hline & & 14 & & & & & \\
\hline & - & FMC & 3.22 & 0.47 & 0.18 & - & - \\
\hline & & 16 & & & & & \\
\hline & - & FMC & 3.58 & 0.41 & 0.08 & 0.12 & Calcite, \\
\hline & & 19 & & & & & quartz \\
\hline & Average & & $3.56 \pm$ & $0.30 \pm$ & $0.12 \pm$ & $0.16 \pm$ & - \\
\hline & & & 0.2 & 0.1 & & 0.1 & \\
\hline
\end{tabular}

\subsection{Bone preservation}

\subsubsection{Infrared spectroscopy}

All of the ATR-FTIR data are presented in Table 5. Statistical analysis revealed that there were no significant differences in IRSF, C/P and Am/P values (Mann-Whitney $\mathrm{p}>0.05$ ) between individual inhumations and ossuary bones. Statistical analysis also revealed that there were significant differences in IRSF and C/P values (Mann-Whitney $\mathrm{p}<0.05$ ) between human and faunal bones, as the latter have lower IRSF and C/P values. However, they show no significant differences in Am/P values (Mann-Whitney $\mathrm{p}>0.05$ ).

Samples collected from various skeletal elements of the same individual skeletons (Table 5) from graves 2, 4, 5, 6 and 7 confirmed intraskeletal differences based on IRSF, C/P and Am/P values.

\subsubsection{X-ray diffraction}

Full details of XRD analyses are listed in Table 5. Statistical analysis showed that there were no significant differences in CI values (MannWhitney $\mathrm{p}>0.05$ ) between individual inhumations and ossuary bones. Statistical analysis also revealed that there were significant differences in $\mathrm{CI}$ values (Mann-Whitney $\mathrm{p}<0.05$ ) between human and faunal bones, which have lower $\mathrm{CI}$ values than human bones. XRD analyses revealed the presence of calcite in the majority of samples (humans and faunal samples). The analysis of two faunal samples (FMC 1 and 19) also revealed the presence of quartz.

Similar to ATR-FTIR analyses, some samples analysed by XRD were collected from different skeletal elements of the same human individual (Table 5) from graves 2, 4, 5, 6 and 7 . The results further corroborate the intra-skeletal differences in crystallinity.

\subsubsection{Collagen quality}

Collagen extraction was successful for most of the human and faunal bone samples, based on the criteria for well-preserved collagen (i.e. $\mathrm{C} / \mathrm{N}$ ratios between 2.9 and 3.6 (DeNiro, 1985), carbon content between 15.3 and 47.0\% (Ambrose, 1990), nitrogen content between 5.5 and 17.3\% (Ambrose, 1990) and collagen yields $>1 \%$ (van Klinken, 1999)). The bone collagen atomic $\mathrm{C} / \mathrm{N}$ ratios for all samples showed ranges between 3.2 and 3.5. The carbon and nitrogen amount in all bone collagen samples ranged from 40.4 to $44.8 \%$ and from 14.2 to $16.1 \%$, respectively. The bone collagen yields showed a large variability, ranging from 0.5 to $12.5 \%$. All the data is listed in Table 6 .

\subsection{Dietary patterns}

All isotopic measurements $\left(\delta^{13} \mathrm{C}_{\mathrm{co}}, \delta^{15} \mathrm{~N}, \delta^{13} \mathrm{C}_{\mathrm{apa}}\right.$ and $\left.\delta^{18} \mathrm{O}_{\text {carb }}\right)$ of human and faunal samples are presented in Table 6. Stable isotope analysis of the human samples from Monte da Cegonha yielded $\delta^{13} \mathrm{C}_{\mathrm{co}}$ values ranging from -17.40 to $-18.80 \%$. $\delta^{15} \mathrm{~N}$ values ranged from 9.40 to $13.20 \%$. Statistical analysis revealed that there were no significant differences in $\delta^{13} C_{\text {co }}$ and $\delta^{15} \mathrm{~N}$ values (Mann-Whitney $\mathrm{p}>0.05$ ) between individual inhumations and ossuary bones, and between female and male individuals (Mann-Whitney $\mathrm{p}>0.05$ ). There were no significant differences in $\delta^{13} \mathrm{C}_{\text {co }}$ values (Mann-Whitney $\mathrm{p}>0.05$ ) between bone samples excavated from graves inside and outside the basilica. However, statistical analysis also revealed that there were significant differences in $\delta^{15} \mathrm{~N}$ values (Mann-Whitney $\mathrm{p}<0.05$ ) between bone samples excavated from graves inside and outside the basilica. Stable isotope analysis of the faunal samples yielded $\delta^{13} \mathrm{C}_{\mathrm{co}}$ values ranging from -18.78 to $-21.38 \%$, and $\delta^{15} \mathrm{~N}$ values ranging from 4.80 to $7.95 \%$.

Stable isotope analysis of the human apatite samples yielded $\delta^{13} \mathrm{C}_{\mathrm{apa}}$ values ranging from -11.57 to $-14.91 \%$. Stable isotope analysis of the faunal samples yielded $\delta^{13} \mathrm{C}_{\text {apa }}$ values ranging from -10.80 to $-12.67 \%$.

A selection of samples from various skeletal elements of individual skeletons from graves 2, 4, 5, 6 and 7, prepared for $\delta^{13} C_{\text {apa }}$, were analysed with and without acetic acid treatment. The analysis was done in order to monitor the potential impact of diagenesis on $\delta^{13} \mathrm{C}_{\mathrm{apa}}$. Results show that 
Table 6

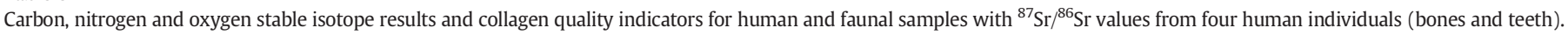

\begin{tabular}{|c|c|c|c|c|c|c|c|c|c|c|c|c|c|}
\hline & \multirow[t]{2}{*}{ Grave } & \multirow[t]{2}{*}{ Sample } & \multirow[t]{2}{*}{ Collagen yield (\%) } & \multirow[t]{2}{*}{$\% \mathrm{C}$} & \multirow[t]{2}{*}{$\% \mathrm{~N}$} & \multirow[t]{2}{*}{$\mathrm{C}: \mathrm{N}$} & \multirow[t]{2}{*}{$\delta^{13} \mathrm{C}_{\mathrm{col}}(\%)$} & \multirow[t]{2}{*}{$\delta^{15} \mathrm{~N}(\%)$} & \multirow[t]{2}{*}{$\delta^{13} C_{\text {apa }}(\%$ ) } & \multirow[t]{2}{*}{$\delta^{13} \mathrm{C}_{\text {apa-col }}(\% \circ)$} & \multirow[t]{2}{*}{$\delta^{18} \mathrm{O}(\%)$} & ${ }^{87} \mathrm{Sr} /{ }^{86} \mathrm{~S}$ & \\
\hline & & & & & & & & & & & & Bone & Tooth \\
\hline Humans - skeletons & 2 & HMC 6 & 7.6 & 43.48 & 15.77 & 3.22 & -18.10 & 10.90 & -14.19 & 3.91 & 1.00 & - & - \\
\hline & & HMC 26 & - & - & - & - & - & - & -15.04 & - & 1.52 & - & - \\
\hline & & HMC 27 & - & - & - & - & - & - & -15.26 & - & 1.24 & - & - \\
\hline & & HMC 28 & - & - & - & - & - & - & -14.91 & - & 2.00 & - & - \\
\hline & 4 & HMC 7 & 8.6 & 44.83 & 16.14 & 3.24 & -18.10 & 11.00 & -14.91 & 3.19 & -0.58 & - & 0.7111 \\
\hline & & HMC 29 & - & - & - & - & - & - & -14.09 & - & -0.29 & - & - \\
\hline & & HMC 30 & - & - & - & - & - & - & -13.99 & - & 0.15 & - & - \\
\hline & & HMC 31 & - & - & - & - & - & - & -14.45 & - & 0.07 & - & - \\
\hline & 5 & HMC 8 & 5.8 & 43.90 & 15.67 & 3.27 & -18.40 & 10.00 & -14.21 & 4.19 & -0.10 & 0.7108 & 0.7108 \\
\hline & & HMC 32 & - & - & - & - & - & - & -14.80 & - & -0.15 & - & - \\
\hline & & HMC 33 & - & - & - & - & - & - & -14.11 & - & 0.16 & - & - \\
\hline & & HMC 34 & - & - & - & - & - & - & -14.17 & - & 0.74 & - & - \\
\hline & 6 & HMC 11 & - & - & - & - & - & - & -13.76 & - & -1.18 & 0.7103 & 0.7097 \\
\hline & & HMC 35 & - & - & - & - & - & - & -14.11 & - & 0.10 & - & - \\
\hline & & HMC 36 & - & - & - & - & - & - & -14.29 & - & -0.19 & - & - \\
\hline & & HMC 37 & - & - & - & - & - & - & -14.08 & - & -1.01 & - & - \\
\hline & 7 & HMC 13 & 6.6 & 44.86 & 15.59 & 3.36 & -18.30 & 9.90 & -11.90 & 6.40 & -1.45 & - & 0.7109 \\
\hline & & HMC 38 & - & - & - & - & - & - & -13.90 & - & -1.71 & - & - \\
\hline & & HMC 39 & - & - & - & - & - & - & -11.67 & - & -1.50 & - & - \\
\hline & & HMC 40 & - & - & - & - & - & - & -14.67 & - & -0.15 & - & - \\
\hline Humans - ossuaries & 1 & HMC 1 & 5.5 & 43.84 & 15.62 & 3.27 & -18.00 & 10.80 & -11.57 & 6.43 & -0.58 & - & - \\
\hline & & HMC 2 & 0.5 & - & - & - & -18.70 & 11.20 & -13.01 & 5.69 & 0.50 & - & - \\
\hline & & HMC 3 & 6.2 & 43.62 & 15.88 & 3.20 & -18.70 & 10.00 & -13.14 & 5.56 & -1.58 & - & - \\
\hline & & HMC 4 & 3.2 & 43.62 & 15.91 & 3.20 & -18.50 & 10.40 & -12.40 & 6.10 & -0.86 & - & - \\
\hline & & HMC 5 & 2.0 & 41.71 & 14.82 & 3.28 & -17.40 & 13.20 & -12.70 & 4.70 & -1.28 & - & - \\
\hline & 5 & HMC 9 & 4.4 & 42.52 & 15.42 & 3.22 & -18.00 & 9.80 & -13.54 & 4.46 & -0.46 & - & - \\
\hline & & HMC 10 & - & - & - & - & - & - & -14.19 & - & -0.95 & - & - \\
\hline & 6 & HMC 12 & 0.6 & - & - & - & -18.20 & 11.60 & -14.23 & 3.97 & -1.02 & - & - \\
\hline & 7 & HMC 14 & 6.3 & 44.37 & 15.76 & 3.29 & -18.80 & 10.50 & - & - & - & - & - \\
\hline & & HMC 15 & 5.8 & 43.58 & 15.80 & 3.22 & -18.00 & 9.60 & - & - & - & - & - \\
\hline & 8 & HMC 16 & 12.5 & 41.31 & 14.27 & 3.38 & -17.90 & 11,20 & -13.54 & 4.36 & 0.74 & - & - \\
\hline & & HMC 17 & 7.5 & 44.33 & 15.84 & 3.27 & -18.70 & 10.10 & -13.42 & 5.28 & 0.66 & - & - \\
\hline & & HMC 18 & 2.3 & 40.38 & 14.25 & 3.31 & -18.40 & 9.60 & -11.70 & 6.70 & -1.21 & - & - \\
\hline & & HMC 19 & 5.2 & 44.15 & 15.42 & 3.34 & -18.30 & 10.10 & -12.84 & 5.46 & -1.24 & - & - \\
\hline & & HMC 20 & 3.9 & 43.68 & 15.14 & 3.37 & -18.40 & 10.80 & -14.01 & 4.39 & -1.76 & - & - \\
\hline & 9 & HMC 21 & 6.7 & 44.12 & 15.77 & 3.26 & -18.60 & 9.70 & -12.67 & 5.93 & -0.72 & - & - \\
\hline & & HMC 22 & 3.9 & 43.24 & 15.65 & 3.22 & -18.70 & 10.20 & -13.55 & 5.15 & -1.21 & - & - \\
\hline & & HMC 23 & 7.7 & 44.01 & 15.90 & 3.23 & -18.40 & 9.40 & -13.71 & 4.69 & -0.31 & - & - \\
\hline & & HMC 24 & 4.7 & 43.41 & 15.68 & 3.23 & -18.40 & 10.40 & -13.81 & 4.59 & -1.57 & - & - \\
\hline & & HMC 25 & 3.8 & 42.77 & 15.47 & 3.23 & -18.60 & 9.60 & -13.58 & 5.02 & -0.94 & - & - \\
\hline Fauna & - & FMC 1 & 0.96 & 41.95 & 14.38 & 3.40 & -21.27 & 7.57 & -11.96 & 9.31 & 0.00 & - & - \\
\hline & - & FMC 2 & 2.0 & 43.48 & 15.65 & 3.24 & -20.49 & 4.80 & -11.75 & 8.74 & -1.25 & - & - \\
\hline & - & FMC 3 & 3.8 & 43.07 & 15.42 & 3.26 & -20.16 & 6.05 & -11.38 & 8.78 & 0.33 & - & - \\
\hline & - & FMC 4 & 1.2 & - & - & - & - & - & -12.29 & - & -1.06 & - & - \\
\hline & - & FMC 5 & 0.7 & 42.84 & 14.22 & 3.51 & -20.27 & 6.64 & -11.04 & 9.23 & -1.34 & - & - \\
\hline & - & FMC 6 & 8.7 & 44.14 & 15.26 & 3.37 & -19.87 & 7.61 & -12.55 & 7.32 & 0.30 & - & - \\
\hline & - & FMC 7 & 1.6 & - & - & - & - & - & -13.36 & - & 0.15 & - & - \\
\hline & - & FMC 8 & 0.7 & - & - & - & - & - & -13.89 & - & -0.51 & - & - \\
\hline & - & FMC 9 & 0.8 & 43.16 & 15.47 & 3.25 & -19.18 & 7.58 & -12.48 & 6.70 & 1.15 & - & - \\
\hline & - & FMC 10 & 5.6 & - & - & - & - & - & -10.45 & - & -0.04 & - & - \\
\hline & - & FMC 11 & 3.9 & 42.54 & 15.02 & 3.30 & -18.78 & 6.95 & -12.44 & 6.34 & 1.00 & - & - \\
\hline & - & FMC 12 & 1.0 & - & - & - & -20.86 & 6.57 & -10.80 & 10.06 & -0.69 & - & - \\
\hline & - & FMC 13 & 2.1 & 42.13 & 15.20 & 3.23 & -20.99 & 6.45 & -11.58 & 9.41 & -0.99 & - & - \\
\hline & - & FMC 14 & 0.5 & - & - & - & -19.24 & 5.51 & -11.76 & 7.48 & -0.05 & - & - \\
\hline & - & FMC 15 & 8.0 & 41.99 & 15.33 & 3.20 & -18.87 & 7.17 & -12.57 & 6.30 & 0.07 & - & - \\
\hline & - & FMC 16 & 6.0 & 43.09 & 15.42 & 3.26 & -19.46 & 7.76 & -11.04 & 8.42 & 0.67 & - & - \\
\hline & - & FMC 17 & 4.9 & 42.03 & 15.15 & 3.24 & -19.99 & 6.73 & -11.31 & 8.68 & 0.28 & - & - \\
\hline & - & FMC 18 & 7.7 & 42.66 & 15.31 & 3.25 & -19.88 & 7.95 & -12.56 & 7.32 & -1.72 & - & - \\
\hline & - & FMC 19 & 4.1 & 42.72 & 15.16 & 3.29 & -19.86 & 7.78 & -11.22 & 8.64 & -0.48 & - & - \\
\hline & - & FMC 20 & 8.8 & 43.12 & 15.39 & 3.27 & -19.00 & 6.16 & -12.67 & 6.33 & 2.67 & - & - \\
\hline & - & FMC 21 & 4.6 & 43.14 & 14.97 & 3.36 & -21.38 & 5.25 & - & - & - & - & - \\
\hline
\end{tabular}

samples without acetic acid treatment present enriched $\delta^{13} C_{\text {apa }}$ values. However, two samples (HMC 13 and 39) from grave 7 also show enriched $\delta^{13} C_{\text {apa }}$ values, although they were treated with acetic acid.

\subsection{Mobility}

Monte da Cegonha's ${ }^{87} \mathrm{Sr} /{ }^{86} \mathrm{Sr}$ ratios of modern water samples were 0.7124 (Fig. 7) while the values for modern vegetation samples ranged from 0.7083 to 0.7125 . Tooth enamel ${ }^{87} \mathrm{Sr} /{ }^{86} \mathrm{Sr}$ ratio values of four individuals (graves $4,5,6$ and 7 ) ranged from 0.7096 to 0.7111 . The bone apatite ${ }^{87} \mathrm{Sr} /{ }^{86} \mathrm{Sr}$ ratios from two different human individuals (graves 5 and 6) varied between 0.7103 and 0.7108 .

Regarding $\delta^{18} \mathrm{O}_{\text {carb }}$, obtained human values range from $-1.76 \%$ o to $1.00 \%$ while faunal sample analysis yielded values ranging from $-1.72 \%$ to $2.67 \%$. Similar to $\delta^{13} C_{\text {apa }}$ we observed differences in $\delta^{18} \mathrm{O}_{\text {carb }}$ values between samples treated and not treated with acetic 
acid, which depleted values, although two samples (HMC 13 and HMC 39) from grave 7 treated with acetic acid behave similarly to untreated samples.

\section{Discussion}

\subsection{Anthropological analysis}

The anthropological data does not allow any conclusions to be made on a population level, due to the small sample size (only five skeletons in articulation), as well as their poor preservation state.

The frequency of dental caries, with two out of four individuals affected, cannot be used to infer diet on a population level but the high number of caries affecting each individual indicates that at least these two had a cariogenic diet, comprising rich starchy food and/or carbohydrates, and negligent dental hygiene. Dental calculus and wear are not significant.

Hypoplastic defects observed on all analysed teeth can be interpreted as the result of physiological stress suffered by these individuals during their early growth, between 1.5 and 3.5 years of age, which corresponds (according to AlQahtani et al. (2010)) to the chronological range of the crown formation of incisors and canines.

\subsection{Bone preservation}

Diagenetic alterations of archaeological bones present a potential problem for the interpretation of isotopic ratios as a source of information for dietary and mobility reconstructions (Hollund et al., 2013; Lebon et al., 2010). Through FTIR and XRD analyses of bone samples it is possible to screen for diagenetic alterations (differences in bone carbonate and collagen content, and in bone crystallinity) in order to understand the reliability of the isotopic data used for dietary and mobility studies.

Principal component analysis involving XRD and FTIR data acquired from human and faunal bones was performed. The correlation circle (Fig. 3) shows a projection of the initial variables (CI, IRSF, C/P and $\mathrm{Am} / \mathrm{P})$ in the factors' space. F1 axis (78.2\% of the variation) correlates strongly with the decreasing values for $\mathrm{C} / \mathrm{P}$ and $\mathrm{Am} / \mathrm{P}$ ratios, while the F2 axis (11.4\% of the variation) correlates positively with Am/P ratio and IRSF, but negatively with $\mathrm{CI}$. The positions of variables $\mathrm{CI}$ and $\mathrm{Am} /$ P suggest they are negatively correlated, i.e., high crystallinity is strongly correlated to lower relative collagen content, which is commonly observed in temperate climates. As the same applies to the variables IRSF and $\mathrm{C} / \mathrm{P}$, an increase in crystallinity is also correlated with a diagenetic loss of carbonate, which is linked to the loss of bone organic matter (Nielsen-Marsh and Hedges, 2000; Person et al., 1995; Salesse et al., 2014). XRD analysis revealed the presence of calcite in 13 samples and the presence of quartz in three samples. The increase of bone porosity, due to the loss of organic matter, subsequently allows interactions between bone components and groundwater, as well as promoting the precipitation of secondary minerals (Lebon et al., 2010), such as calcite. Therefore, FTIR and XRD analysis indicate that the samples have been diagenetically transformed in comparison to fresh bones (IRSF $>3.4$ (Beasley et al., 2014; Berna et al., 2004; Salesse et al., 2014), C/P values out of the range 0.23 to 0.34 (Beasley et al., 2014), Am/P values below 0.9 (Salesse et al., 2014) and CI >0 (Person et al., 1996)).

FTIR and XRD also indicate that there are no differences in preservation between overall individual inhumations and ossuary bones. On the other hand, faunal bone samples were less altered compared to human bone samples. Such alteration can be due to a different burial context. Faunal remains were excavated outside the basilica at various locations, suggesting that they could be domestic refuse.

Bone samples from graves 2, 4, 5, 6 and 7, analysed by FTIR and XRD, were collected from different skeletal elements of the same individual to check for intra-skeletal differences. Results show that there are differences in crystallinity at the intra-skeletal scale, as well as at the grave

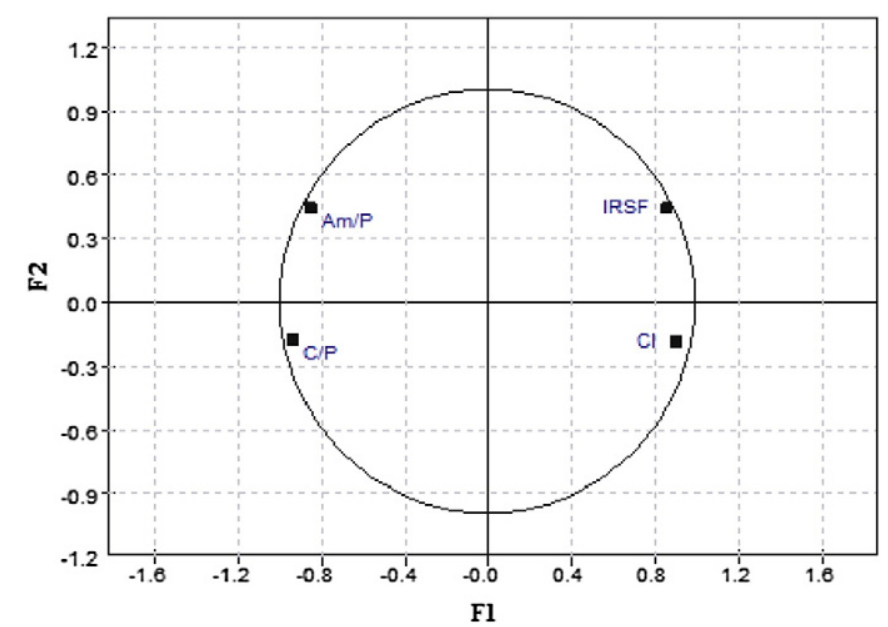

Fig. 3. Correlation circle for principal components 1 and 2 after principal component analysis of FTIR and XRD data.

level, between primary inhumations and ossuaries buried in the same grave (Table 5). These intra-skeletal differences may be due to taphonomic processes and differential kinetic diffusion parameters depending on the part of the skeleton and the individuals analysed (Maurer et al., 2011).

Additionally, six samples were analysed with and without acetic acid treatment to better understand the diagenetic trajectory of the $\delta^{13} \mathrm{C}_{\mathrm{apa}}$ and $\delta^{18} \mathrm{O}_{\text {carb }}$ isotopic ratios. Although, acetic acid can have an impact on sample stable isotope values, with increasing $\delta^{18} \mathrm{O}$ values (GarvieLok et al., 2004), acetic acid is usually used to remove calcite precipitated in bone porosity, before analysing bone apatite $\delta^{13} \mathrm{C}$ and $\delta^{18} \mathrm{O}$. Results show that samples without acetic acid treatment present enriched $\delta^{13} \mathrm{C}_{\mathrm{apa}}$ and depleted $\delta^{18} \mathrm{O}_{\text {carb }}$ values (Fig. 4). Moreover, as can be seen from Fig. 4, two samples from grave 7 (HMC 13 and 39) although treated with acetic acid show relatively enriched $\delta^{13} \mathrm{C}_{\text {apa }}$ values, which may indicate that these two samples are "on the diagenetic trajectory" and should therefore be excluded from palaeodietary reconstruction. Skeletons, $2,4,5,6$, do not show important isotopic intra-skeletal differences $\left(\delta^{13} C_{a p a}<0.5 \%\right.$ and $\delta^{18} \mathrm{O}_{\text {carb }}<0.6 \%$ o at the intra-skeletal scale) nor any values "on the diagenetic trajectory" indicating the preservation of their isotopic composition.

In summary, although modified post-mortem, according to collagen parameters $(\mathrm{C} / \mathrm{N}$ ratio, \% $\%$, N collagen yield) and results issued from FTIR and XRD analysis, the isotopic information obtained is, overall, reliable for reconstructing diet and mobility of this Late Antiquity population.

\subsection{Dietary patterns}

In order to accurately determine isotopic signatures $\left(\delta^{13} \mathrm{C}_{\mathrm{co}}, \delta^{15} \mathrm{~N}\right.$ and $\delta^{13} \mathrm{C}_{\mathrm{apa}}$ ) of food sources potentially consumed by the human population, it is essential to determine the isotopic values of contemporaneous animal remains (Jørkov et al., 2010; Stevens et al., 2012).

The wild animals analysed (red deer and rabbit), show carbon isotopic ratios typical for terrestrial wild herbivores that feed on $C_{3}$ plants $\left(\delta^{13} \mathrm{C}_{\text {co }}\right.$ median $=-20.94 \%$; 25 th percentile: $-24.16 \%$, 50 th percentile: $-20.94 \%$; 75th percentile: $-20.71 \%$; Fig. 5 and Table 6; Schoeninger and DeNiro, 1984; Schoeninger and Moore, 1992). Domestic fauna, cattle and ovicaprines, show relatively similar $\delta^{13} \mathrm{C}_{\mathrm{co}}$ (average $=-20.41 \pm 0.70 \%$ ) or enriched $\delta^{13} C_{\text {co }}$ (average $=-19.30 \pm$ $0.50 \%$ ) values, respectively, in comparison to wild animals (Fig. 5 and Table 6). The enrichment observed for ovicaprines may be due to the consumption of $\mathrm{C}_{4}$ plants. Occasional finds of millet seeds provide some evidence for its introduction to Northern Italy by the Early Bronze Age (Tafuri et al., 2009). Written historical sources reveal that millet 


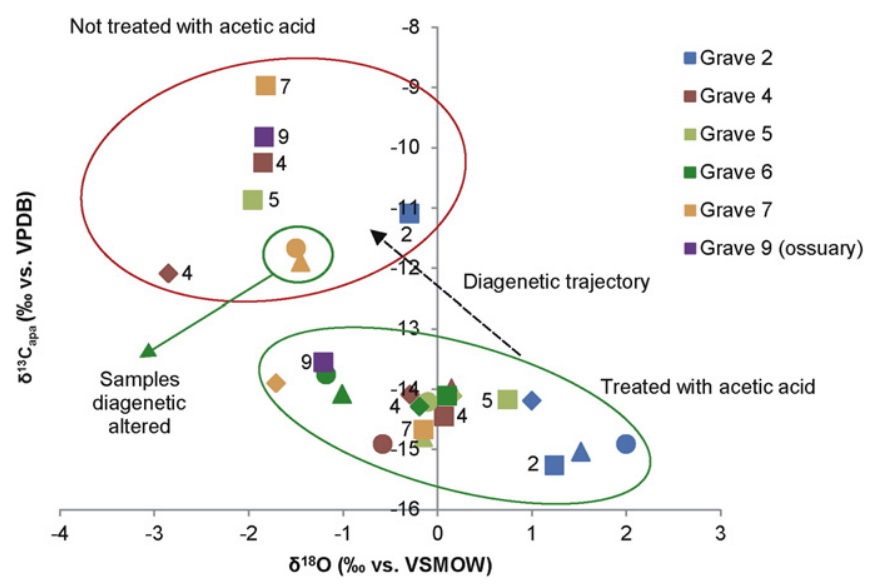

Fig. 4. Oxygen and carbon isotope composition from human bone apatite samples from graves 2, 4, 5, 6, 7 (primary inhumations) and 9 (ossuary). Data are provided for samples pre-treated with acetic acid (highlighted with a green circle) as well as for samples with no acetic acid treatment (highlighted in red). Samples submitted to both treatments are accompanied with their grave number, and represented with the same symbol. When other skeletal elements were analysed from the same individual, they are represented with different symbols but with the same color.

was grown for human consumption as well as animal fodder in Italy, during the Roman and Medieval periods (Tafuri et al., 2009). In the Iberian Peninsula, the earliest evidence for millet is dated to the 3rd century CE in the Portuguese site of Castro de Palheiros (Moreno-Larrazabal et al., 2015). According to Tereso (2007), one of the most cultivated species in the site of Terronha de Pinhovelo (Northeast Portugal) during the 4th and 5th centuries CE was millet. However, there is no archaeobotanical data confirming the cultivation of millet at Monte da Cegonha. Moreover, the slightly enriched $\delta^{13} \mathrm{C}_{\mathrm{co}}$ values for ovicaprines could also arise from the consumption of different $C_{3}$ plants; or plant tissue with enriched $\delta^{13} \mathrm{C}_{\mathrm{co}}$ values (Dungait et al., 2011); or plants growing in fields subjected to different irrigation practices (Stokes et al., 2011).

Concerning the $\delta^{15} \mathrm{~N}$ values (Fig. 5), cattle and ovicaprine animals display enriched $\delta^{15} \mathrm{~N}$ ratios (average $=6.90 \pm 0.70 \%$ ) in comparison to wild herbivores, i.e., red deer and rabbit ( median $=5.03 \%$; 25 th percentile: $4.91 \%$, 50 th percentile: $5.03 \%$; 75 th percentile: $5.14 \%$ ). This $\delta^{15} \mathrm{~N}$ enrichment may be the result of field manuring where domesticated animals were kept (Bogaard et al., 2007). The application of animal dung results in artificially raised $\delta^{15} \mathrm{~N}$ values in soil and plants, causes a significant enrichment in bone $\delta{ }^{15} \mathrm{~N}$ values of animals and human consumers (Bogaard et al., 2007; van Klinken et al., 2000). Furthermore,

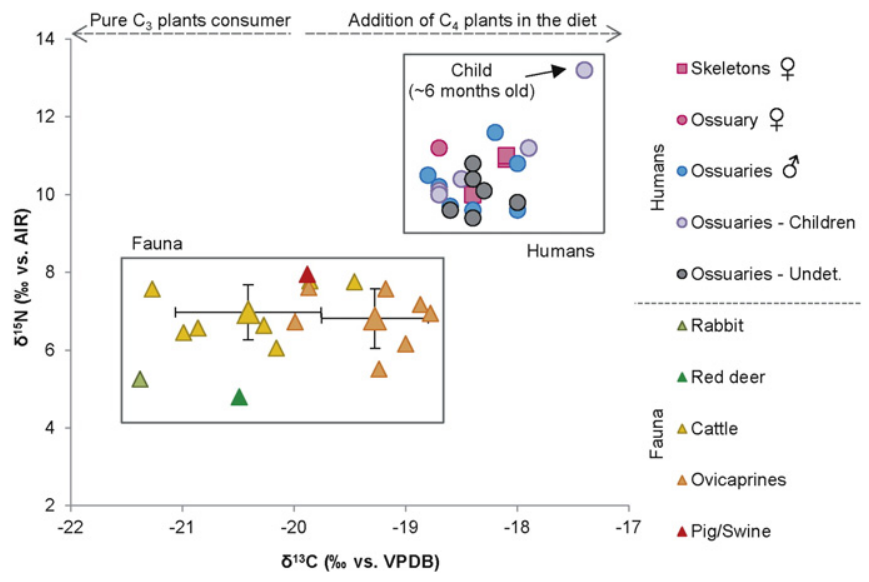

Fig. 5. Bone collagen carbon and nitrogen isotope data from human and faunal remains recovered at Monte da Cegonha. Cattle and ovicaprines $\delta^{13} \mathrm{C}$ and $\delta^{15} \mathrm{~N}$ ratios with average $\pm 1 \sigma$ are indicated. $\delta^{15} \mathrm{~N}$ of plants may be affected by differences in temperature, precipitation and nitrogen content in soil, even in the same locality (Amundson et al., 2003). Swine $\delta^{13} C_{\text {co }}$ and $\delta^{15} \mathrm{~N}$ values ( $-19.88 \%$ and $7.95 \%$, respectively; Fig. 5 and Table 6 ) are clustered with cattle and ovicaprine values, which suggests a similar herbivorous diet (Craig et al., 2009; Knipper et al., 2012; Prowse et al., 2004; Vika, 2011). Zooarchaeological analyses of the swine specimen were not able to distinguish between domestic pig and wild boar (Albarella et al., 2005; Valente and Carvalho, 2014) but, given the residential/farming status of the site, most of the swine remains can be attributed to domestic animals.

As can be seen from Fig. 5 and Table 6, most of the human collagen $\delta^{13} \mathrm{C}_{\mathrm{co}}$ and $\delta^{15} \mathrm{~N}$ values are closely clustered, with a single notable outlier (HMC 5) associated with an enriched $\delta^{15} \mathrm{~N}$ value. This individual was an infant ( 6 months), whose $\delta^{15} \mathrm{~N}$ value of $13.20 \%$, is around 3\% above the average $\delta^{15} \mathrm{~N}$ value for the human population of Monte da Cegonha. This $\delta^{15} \mathrm{~N}$ enrichment seems to indicate a nursing signal. Some authors have addressed the issue of breastfeeding and weaning practices by analysing teeth (Richards et al., 2002; Beaumont et al., 2013, 2015) while others have investigated bone samples (Dupras et al., 2001; Fuller et al., 2006; Jørkov et al., 2010). In this study, breastfeeding and weaning was investigated using bone samples as teeth were not available for infant. When infants are breastfed, all protein is obtained from their mother's milk (Dupras et al., 2001), and thus $\delta^{15} \mathrm{~N}$ values of the infant's collagen reflect a trophic shift of 2 to $3 \%$ compared to the mother (Dupras et al., 2001; Fuller et al., 2006). The $\delta^{15} \mathrm{~N}$ collagen ratios of four other infants analysed (HMC 3, 4, 16 and 17; aged 38 weeks in uterus1.5 months, 6 months- 1 year, three and five years old) plot closely to the adult isotope ratios, suggesting that these

individuals were either not breastfed or had already been weaned (Budd et al., 2013). Weaning practices of the Roman era were described by Soranus and Galen, medical scholars of the Roman world ( $2^{\text {nd }}$ century AD) (Dupras et al., 2001; Fuller et al., 2006). They reported that supplementary foods (boiled honey or a mixture of honey and goat's milk) were introduced gradually at 6 months of age, with complete termination of breastfeeding by 3 years of age. During the weaning process, the introduction of supplementary foods results in a gradual depletion of infant $\delta^{15} \mathrm{~N}$, reaching adult values when the child is fully weaned (Dupras et al., 2001; Fuller et al., 2006). Average enrichment in bone $\delta^{13} \mathrm{C}_{\mathrm{co}}$ and $\delta{ }^{15} \mathrm{~N}$ values of the humans analysed (at approximately $1.5 \%$ and $3.8 \%$, respectively), is consistent with a trophic level enrichment between herbivores and carnivores. Both carbon and nitrogen isotopic values therefore suggest that animal meat constituted an important dietary protein resource for the human population of Monte da Cegonha. Therefore, the human $\delta^{13} \mathrm{C}_{\mathrm{co}}$ and $\delta^{15} \mathrm{~N}$ collagen signatures observed suggest that $C_{3}$ plants were the basis of the Monte da Cegonha population diet, complemented with meat from terrestrial herbivores alongside their by-products with perhaps some input of $\mathrm{C}_{4}$ plants. This $\mathrm{C}_{4}$ input could be due to the consumption of domestic animals, which were fed $\mathrm{C}_{4}$ with plants.

The results from Monte da Cegonha are consistent with the Roman diet, as reported in literature sources, which focused on a "Mediterranean triad" of cereals, wine and olive oil, together with dry legumes (Keenleyside et al., 2009; Prowse et al., 2005). Prowse et al. (2004) suggested that cereals made up around $70-75 \%$ of the dietary intake of the Roman diet, while meat and other animal products were not major dietary components. Pork was the most popular meat consumed by the Romans, followed by sheep and goats' meat (approximately 25 to $50 \%$ ). However, consumption varied by region and chronology (King, 1999). Zooarchaeological studies concur that the predominant domesticates in Southern Portugal during the Roman period and Late Antiquity were ovicaprines (sheep and goats) and pigs, followed by cattle (for the Alentejo region see: MacKinnon, 1999-2000; Cardoso and Detry, 2005; similar results for Horta da Torre (personal communication by M. J. Valente)). Ovicaprines were kept primarily for secondary products, such as wool, milk and cheese, while beef represented only a small component of the Roman diet because cattle were used primarily as draft 
animals. This dietary picture is consistent with the results obtained from human and animal bone collagen stable isotopic composition analysis. The human $\delta^{13} \mathrm{C}_{\mathrm{co}}$ and $\delta^{15} \mathrm{~N}$ isotopic collagen signatures also revealed that there were no dietary differences related to gender and burial type (primary inhumations versus ossuary bones, sarcophagus versus other graves). However, human $\delta^{15} \mathrm{~N}$ isotopic collagen signatures revealed dietary differences related to grave location (graves inside versus outside the basilica), potentially due to social stratification in dietary habits.

Comparison with other roughly contemporaneous European sites revealed similar diets as well as dietary practices which rarely show sex and age related patterns (Chenery et al., 2010; Killgrove and Tykot, 2013; Müldner et al., 2011; Pollard et al., 2011; Prowse et al., 2004, 2005; Rutgers et al., 2009; Stevens et al., 2012). Overall, these studies (including the results discussed herein) show that the diet of these populations was more dependent on the environment and local availability of food sources rather than on cultural habits.

Although currently under debate, the application of $\delta^{13} \mathrm{C}_{\text {apa-col }}$ spacing allows discrimination of trophic levels (Sponheimer and Cerling, 2014), as $\delta^{13} C_{\text {apa-col }}$ increases with decreasing trophic level

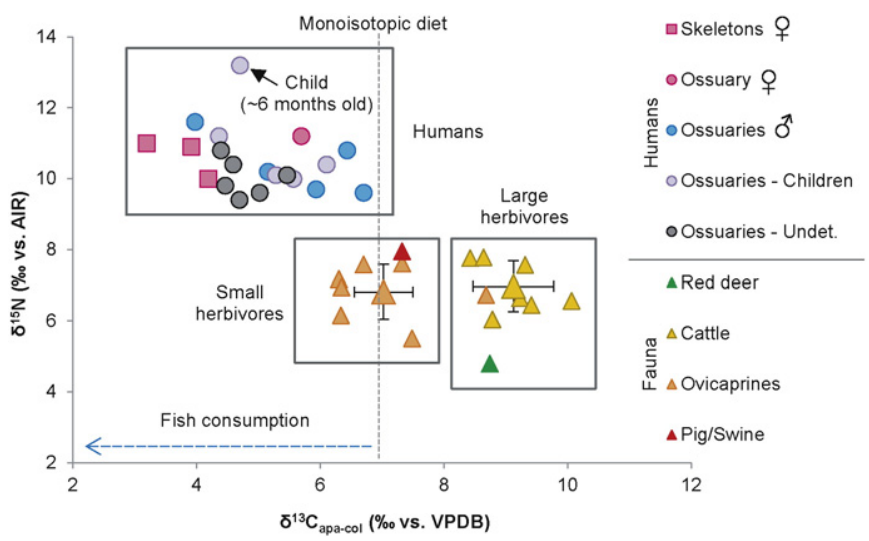

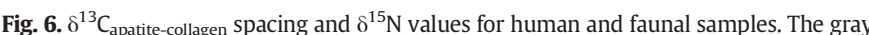
dashed line corresponds to values reported for monoisotopic diet (Salesse et al., 2013). The blue dashed line corresponds to a theoretical dietary increase of fish consumption. Cattle and ovicaprines $\delta^{13} C_{\text {apatite-collagen }}$ and $\delta^{15} \mathrm{~N}$ ratios with average $\pm 1 \sigma$ are indicated.
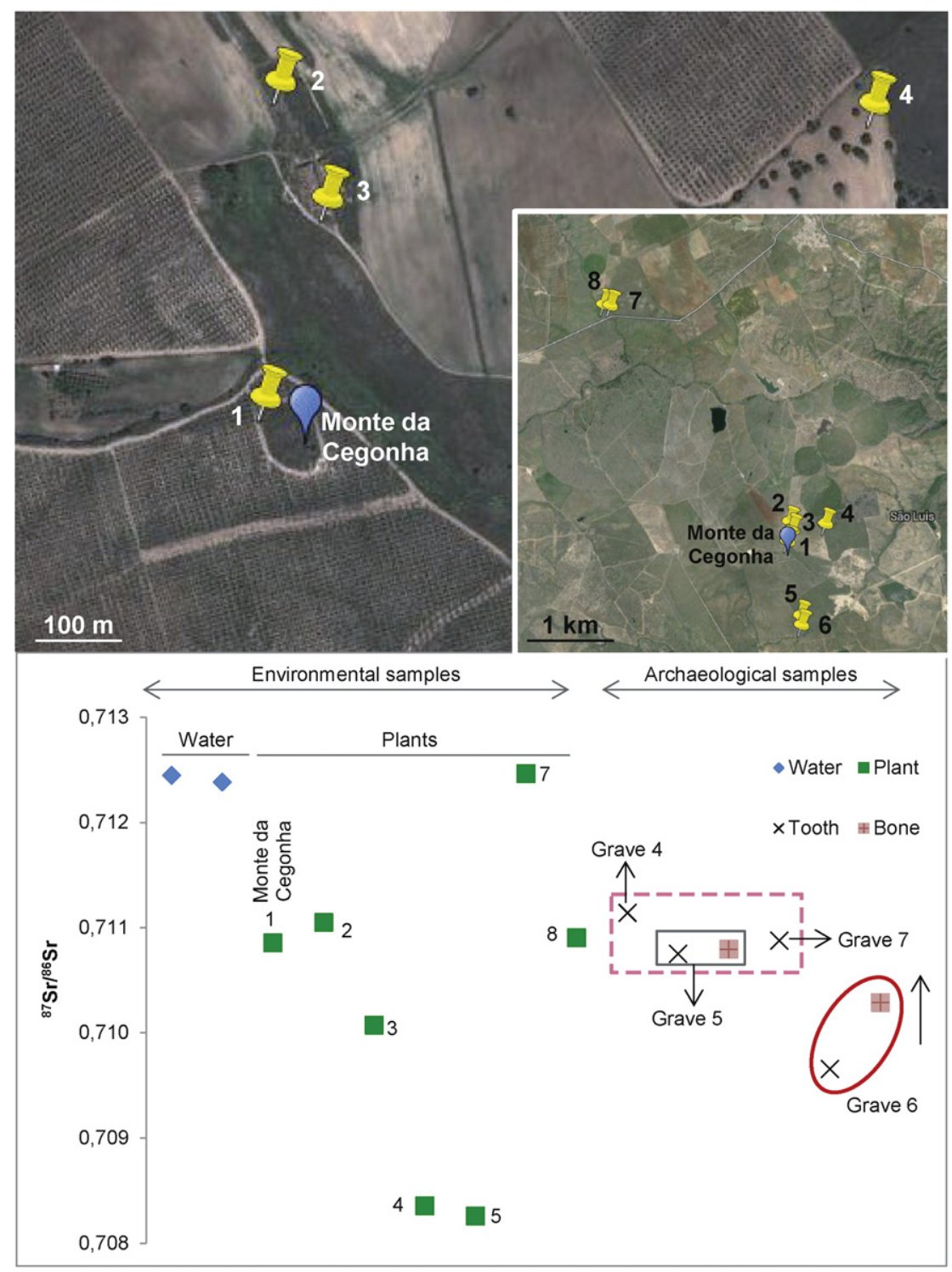

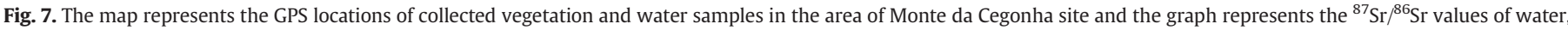

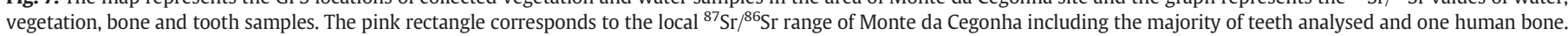
Plant numbers indicate samples on the map. The red circle represents a potentially non-local ${ }^{87} \mathrm{Sr} /{ }^{86} \mathrm{Sr}$ signal from the individual in grave 6 . 
(Keenleyside et al., 2009). Herbivores have $\delta^{13} C_{\text {apa-col values of } 7 \% \text { 。 }}$ (Ambrose et al., 2003) and carnivores have values of 3-4\% (Ambrose

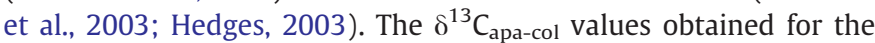
human population and animal species are reported in Fig. 6 and Table 6 . The $\delta{ }^{13} \mathrm{C}_{\mathrm{apa} \text {-col }}$ values for herbivores fall within the previously reported range (7\%; Ambrose et al., 2003) however, there are $\delta^{13} C_{\text {apa- }}$ col differences between large (cattle and red deer) and small herbivores (ovicaprines and swine). Cattle exhibit enriched $\delta^{13} \mathrm{C}_{\text {apa-col }}$ values, probably due to methanogenesis (Hedges, 2003). According to Ambrose and Krigbaum (2003), ruminant herbivores have symbiotic digestive microbes that produce large amounts of methane. As such, apatite is enriched relative to diet but collagen enrichment is unchanged, resulting in higher $\delta^{13} C_{\text {apa-col }}$ values in ruminant herbivores. As physiological differences appear to be preserved between large and small herbivores in this study, the isotopic dataset has not been altered by diagenetic modifications.

As can be seen from Fig. 6 and Table 6 the relatively low $\delta^{13} \mathrm{C}_{\text {apa-col }}$ spacing $(<7 \%$ ) exhibited by the humans from Monte da Cegonha indicates that the protein component of their diet is ${ }^{13} \mathrm{C}$-enriched compare to the whole diet (Salesse et al., 2013) and that the presence of lipids in the diet reduced the carbon isotope spacing values (München, 2007). Fig. 6 further suggests that four of the five children (HMC 3, 4, 16 and 17) were consuming the same food as the adults in the population and that these individuals were weaned. Freshwater intake may have been reflected in some skeletons with fairly low $\delta^{13} \mathrm{C}_{\text {apa-col }}$ spacing (around 4\%; Fig. 6), but the relatively depleted $\delta^{15} \mathrm{~N}$ values observed suggest that this consumption was minimal, perhaps in the form of low trophic fish or fish sauces produced from such species (Prowse et al., 2004). According to Prowse et al. (2004), fish were considered an expensive food item in the Roman diet, suggesting that regular fish consumption may have been restricted to elite members of society, especially in regions located far from the coast. Fish were also consumed salted (salsamenta) and in the form of various fish sauces (e.g., liquamen, garum) (Prowse et al., 2004).

\subsection{Mobility}

As can be seen from Fig. 7 and Table 6, it is apparent that the individuals from graves 4,5 and 7 have ${ }^{87} \mathrm{Sr} /{ }^{86} \mathrm{Sr}$ ratios that are comparable to vegetation samples collected around the Roman villa. A tooth from the individual buried in grave 6 presented lower ${ }^{87} \mathrm{Sr} /{ }^{86} \mathrm{Sr}$ ratios in comparison to ${ }^{87} \mathrm{Sr} /{ }^{86} \mathrm{Sr}$ recorded in this individual's femur which is closer to the local bioavailable ${ }^{87} \mathrm{Sr} /{ }^{86} \mathrm{Sr}$ signal. This suggests that this male individual could be local to the geographical area but non-local to the site of Monte da Cegonha. This shift in the ${ }^{87} \mathrm{Sr} /{ }^{86} \mathrm{Sr}$ signature may have occurred in later life or post-mortem. Considering that the observed $\delta^{18} \mathrm{O}_{\text {carb }}$ value does not appear to be diagenetically impacted (cf. 6.2.), individual 6 appears to have resided at Monte da Cegonha long enough for the $\delta^{18} \mathrm{O}_{\text {carb }}$ to be the same as individuals 4, 5 and 7, as well as the small and large herbivores studied (see Fig. 8). Interestingly, the individual from grave 2 had the most enriched $\delta^{18} \mathrm{O}_{\text {carb }}$ value compared to other graves, ossuaries and faunal remains (small and large herbivores) found in Monte da Cegonha. Additionally, this individual presented one of the lowest $\delta^{13} \mathrm{C}_{\text {apa-col }}$ spacings ( $<4 \%$ ) probably reflecting fish consumption (Fig. 6). As this individual was interred inside a white marble sarcophagus (see Fig.2), access to different water resources and a higher fish consumption may reflect a different social status or provenance. Teeth from this individual were not available sampling.

\section{Conclusions}

The stable isotope analysis of human and animal remains from the site of Monte da Cegonha provides the first dietary evidence of a Late Antiquity population in southern Portugal.

Anthropological analysis revealed no dietary-driven gender differences. However, the frequency of dental caries indicated a cariogenic

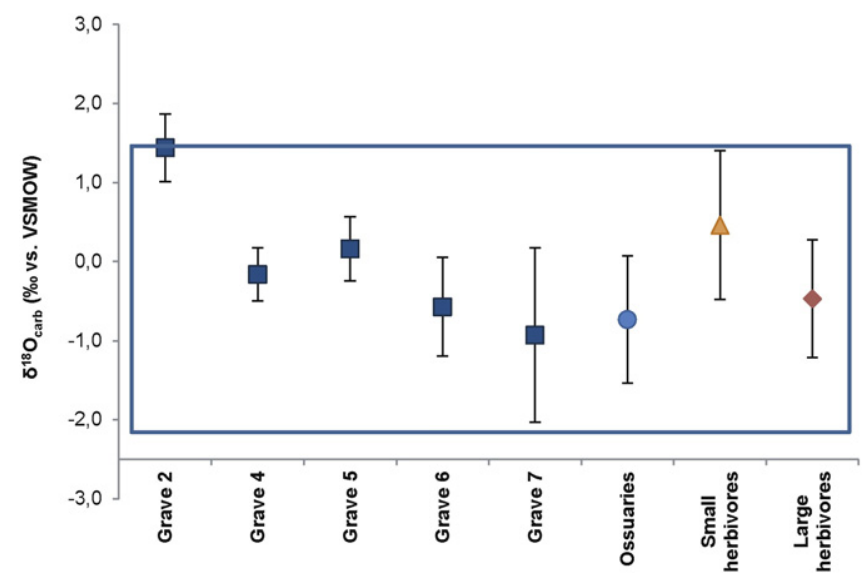

Fig. 8. Oxygen isotope values of bone apatite samples from inhumations 2, 4, 5, 6 and 7, ossuaries as well as small and large herbivores displayed as average values $\pm 1 \sigma$. The blue rectangle includes all human individuals (primary inhumations and ossuaries) and the small and large herbivores. $\delta^{18} \mathrm{O}_{\text {carb }}$ values obtained from grave 2 stand out of this rectangle.

diet comprising rich starchy food and carbohydrates for at least two individuals alongside poor dental hygiene. Mineralogical and geochemical investigation of bone preservation affirmed the reliability of isotopic results for dietary and mobility studies, despite slight diagenetical transformation. Isotopic data confirmed the results of anthropological analyses and indicated that people from Monte da Cegonha consumed a diet consisting of $C_{3}$ plants, complemented by some meat from terrestrial herbivores and their secondary products. Low nitrogen isotopic ratios suggest minimal freshwater fish intake, or perhaps low trophic level fish or fish sauce consumption, as reflected by the low $\delta^{13} C_{\text {apa-col }}$ spacings obtained.

Dietary differences were not observed for gender or burial type. In contrast, isotopic data implied dietary differences between adults and one very young infant that exhibited a nursing signal. Four other children of varying age plotted closely to the adult isotope ratios and were likely already weaned.

Finally, strontium and oxygen isotopic ratios revealed a sedentary community, with the exception of a male individual who may have been a geographical local but non-local to the site of Monte da Cegonha. A single female individual buried in a marble sarcophagus, suggesting a different social status, was characterized by an enriched potentially non-local $\delta^{18} \mathrm{O}_{\text {carb }}$ signature as well as a relatively low $\delta^{13} \mathrm{C}_{\text {apa-col }}$ spacing likely suggesting more frequent access to fish products.

\section{Acknowledgements}

This study is part of the research project "HEROICA: Health and Edibles in ROman Iberia - a Case-study for Archaeometry" (PTDC/HIS-ARQ/ 120236/2010) co-funded by the Portuguese Science and Technology Foundation (FCT) and by the European Regional Development Fund (ERDF) through the Operational Programme Competitiveness Factors (COMPETE). The authors would like to thank Marie Balasse and Denis Fiorillo from the National Museum of Natural History (MNHN) in Paris for the analysis of apatite samples, Corina Knipper and Marcus Stecher for helping substantially with collagen procedure, Catarina Miguel for helping with FTIR analysis, José Mirão for helping with XRD analysis and Pedro Barrulas for helping with Sr analysis. Thanks also go to Patrícia Moita for helping with the fieldtrip to Monte da Cegonha and to Iain White for proof reading the manuscript. Lastly, the authors would like to thank the three anonymous reviewers for suggestions and improvement of the manuscript. 


\section{References}

Alarcão, A.M., Lopes, C., Alfenim, R., 1992. A caixa relicário do Monte da Cegonha (Selmes-Vidigueira). IV Reunió d'Arqueologia Cristiana Hispânica, pp. 401-405.

Albarella, U., Davis, S.J.M., Detry, C., Rowley-Conwy, P., 2005. Pigs of the 'Far West': the biometry of Sus from archaeological sites in Portugal. Anthropozoologica 40 (2), 27-54.

Alfenim, R., Lopes, C., 1992. . A basílica Paleocristã/Visigótica do Monte da Cegonha (Vidigueira). IV Reunió d'Arqueologia Cristiana Hispânica, pp. 389-398.

AlQahtani, S.J., Hector, M.P., Liversidge, H.M., 2010. Brief communication: the London atlas of human tooth development and eruption. Am. J. Phys. Anthropol. 142, 481-490. http://dx.doi.org/10.1002/ ajpa.21258.

Ambrose, S.H., 1990. Preparation and characterization of bone and tooth collagen for isotopic analysis. J. Archaeol. Sci. 17, 431-451. http://dx.doi.org/10.1016/0305-4403(90)90007-R.

Ambrose, S.H., Krigbaum, J., 2003. Bone chemistry and bioarchaeology. J. Anthropol. Archaeol. 22, 193-199. http://dx.doi.org/10.1016/ S0278-4165(03)00033-3.

Ambrose, S.H., Norr, L., 1993. Experimental evidence for the relationship of the carbon isotope ratios of whole diet and dietary protein to those of bone collagen and carbonate. In: Lambert, J.B., Grupe, G. (Eds.), Prehistoric Human Bone Archaeology at the Molecular Level. Springer, Berlin Heidelberg, pp. 1-37 http://dx.doi.org/10. 1007/978-3-662-02894-0 1.

Ambrose, S.H., Buikstra, J., Krueger, H.W., 2003. Status and gender differences in diet at Mound 72, Cahokia, revealed by isotopic analysis of bone. J. Anthropol. Archaeol. 22, 217-226. http://dx.doi.org/10. 1016/S0278-4165(03)00036-9.

Amundson, R., Austin, A.T., Schuur, E.A.G., Yoo, K., Matzek, V., Kendall, C., Uebersax, A., Brenner, D., Baisden, W.T., 2003. Global patterns of the isotopic composition of soil and plant nitrogen. Glob. Biogeochem. Cycles 17 (1), 1031. http://dx.doi.org/10.1029/ 2002GB001903 (2003).

Beasley, M.M., Bartelink, E.J., Taylor, L., Miller, R.M., 2014. Comparison of transmission FTIR, ATR, and DRIFT spectra: implications for assessment of bone bioapatite diagenesis. J. Archaeol. Sci. 46, 16-22. http://dx.doi.org/10.1016/j.jas.2014.03.008.

Beaumont, J., Gledhill, A., Lee-Thorp, J., Montgomery, J., 2013. Childhood diet: a closer examination of the evidence from dental tissues using stable isotope analysis of incremental human dentine. Archaeometry 55 (2), 277-295. http://dx.doi.org/10.1111/j.14754754.2012.00682.x.

Beaumont, J., Montgomery, J., Buckberry, J., Jay, M., 2015. Infant mortality and isotopic complexity: new approaches to stress, maternal health, and weaning. Am. J. Phys. Anthropol. 157 (3), 441-457. http://dx.doi.org/10.1002/ajpa.22736.

Beck, L.A., 1995. Standards for data collection from human skeletal remains. Fayetteville: Arkansas Archeological Survey Research Series No. 44 http://dx.doi.org/10.1002/ajhb.1310070519.

Bentley, R.A., 2006. Strontium isotopes from the earth to the archaeological skeleton: a review. J. Archaeol. Method Th. 13 (3), 135-187. http://dx.doi.org/10.1007/s10816-006-9009-x.

Berna, F., Matthews, A., Weiner, S., 2004. Solubilities of bone mineral from archaeological sites: the recrystallization window. J. Archaeol. Sci. 31, 867-882. http://dx.doi.org/10.1016/j.jas.2003. 12.003.

Bocherens, H., Drucker, D., 2003. Trophic level isotopic enrichment of carbon and nitrogen in bone collagen: case studies from recent and ancient terrestrial ecosystems. Int. J. Osteoarchaeol. 13, 46-53. http://dx.doi.org/10.1002/oa.662.

Bogaard, A., Heaton, T.H.E., Poulton, P., Merbach, I., 2007. The impact of manuring on nitrogen isotope ratios in cereals: archaeological implications for reconstruction of diet and crop management practices. J. Archaeol. Sci. 34, 335-343. http://dx.doi.org/10.1016/j.jas.2006.04. 009 .
Brettell, R., Montgomery, J., Evans, J., 2012. Brewing and stewing: the effect of culturally mediated behaviour on the oxygen isotope composition of ingested fluids and the implications for human provenance studies. J. Anal. At. Spectrom. 27, 778-785. http://dx.doi.org/ 10.1039/c2ja10335d.

Britton, K., Müldner, G., Bell, M., 2008. Stable isotope evidence for saltmarsh grazing in the Bronze Age Severn Estuary, UK: implications for palaeodietary analysis at coastal sites. J. Archaeol. Sci. 35 2111-2118. http://dx.doi.org/10.1016/j.jas.2008.01.012.

Brothwell, D.R., 1981. Digging Up Bones: The Excavation, Treatment, and Study of Human Skeletal Remains. Cornell University Press, Ithaca, New York.

Brown, T., Brown, K., 2011. Biomolecular Archaeology, An Introduction. Wiley-Blackwell, Chichester.

Bruzek, J., 2002. A method for visual determination of sex, using the human hip bone. Am. J. Phys. Anthropol. 117, 157-168. http://dx. doi.org/10.1002/ajpa.10012.

Budd, C., Lillie, M., Alpaslan-Roodenberg, S., Karul, N., Pinhasi, R., 2013. Stable isotope analysis of Neolithic and Chalcolithic populations from Aktopraklık, northern Anatolia. J. Archaeol. Sci. 40, 860-867. http://dx.doi.org/10.1016/j.jas.2012.09.011.

Bull, G., Payne, S., 1982. Tooth eruption and epiphysial fusion in pigs and wild boar. In: Wilson, B., Grigson, C., Payne, S. (Eds.), Ageing and Sexing Animal Bones from Archaeological Sites. British Archaeological Reports British Series 109, pp. 55-71 Oxford.

Cardoso, J.L., Detry, C., 2005. A lixeira baixo-imperial da uilla da Quinta das Longas (Elvas): análise arqueozoológica e significado económico-social. Revista Portuguesa de Arqueologia 8 (1), 369-386.

Cardoso, H.F.V., Gomes, J.E.A., 2009. Trends in adult stature of peoples who inhabited the modern Portuguese territory from the Mesolithic to the late 20th century. Int. J. Osteoarchaeol. 19, 711-725. http:// dx.doi.org/10.1002/ao.991.

Chenery, C., Müldner, G., Evans, J., Eckardt, H., Lewis, M., 2010. Strontium and stable isotope evidence for diet and mobility in Roman Gloucester, UK. J. Archaeol. Sci. 37, 150-163. http://dx.doi.org/10. 1016/j.jas.2009.09.025.

Craig, O.E., Biazzo, M., O'Connell, T.C., Garnsey, P., Martinez-Labarga, C., Lelli, R., Salvadei, L., Tartaglia, G., Nava, A., Renò, L., Fiammenghi, A., Rickards, O., Bondioli, L., 2009. Stable isotopic evidence for diet at the Imperial Roman coastal site of Velia (1st and 2nd centuries AD) in Southern Italy. Am. J. Phys. Anthropol. 139, 572-583. http://dx.doi.org/10.1002/ajpa.21021.

Dansgaard, W., 1964. Stable isotopes in precipitation. Tellus 16 (4), 436-468. http://dx.doi.org/10.1111/j.2153-3490.1964.tb00181.x.

DeNiro, M.J., 1985. Postmortem preservation and alteration of in vivo bone collagen isotope ratios in relation to palaeodietary reconstruction. Nature 317, 806-809. http://dx.doi.org/10.1038/317806a0.

Dungait, J.A.J., Docherty, G., Straker, V., Evershed, R.P., 2011. Variation in bulk tissue, fatty acid and monosaccharide $\delta^{13} \mathrm{C}$ values between autotrophic and heterotrophic plant organs. Phytochemistry 72 , 2130-2138. http://dx.doi.org/10.1016/j.phytochem.2011.07.010.

Dupras, T.L., Schwarcz, H.P., Fairgrieve, S.I., 2001. Infant feeding and weaning practices in Roman Egypt. Am. J. Phys. Anthropol. 115, 204-212. http://dx.doi.org/10.1002/ajpa.1075.

Ferembach, D., Schwidetzky, I., Stoukal, M., 1980. Recommendations for age and sex diagnosis of skeletons. J. Hum. Evol. 9, 517-549. http:// dx.doi.org/10.1016/0047-2484(80)90061-5.

Fuller, B.T., Molleson, T.I., Harris, D.A., Glimour, L.T., Hedges, R.E.M., 2006. Isotopic evidence for breastfeeding and possible adult dietary differences from Late/Sub-Roman Britain. Am. J. Phys. Anthropol. 129, 45-54. http://dx.doi.org/10.1002/ajpa.20244.

Garvie-Lok, S.J., Varney, T.L., Katzenberg, M.A., 2004. Preparation of bone carbonate for stable isotope analysis: the effects of treatment time and acid concentration. J. Archaeol. Sci. 31, 763-776. http:// dx.doi.org/10.1016/j.jas.2003.10.014.

Grant, A., 1982. The use of tooth wear as a guide to the age of domestic ungulates. In: Wilson, B., Grigson, C., Payne, S. (Eds.), Ageing and 
Sexing Animal Bones from Archaeological Sites. British Archaeological Reports British Series 109, pp. 91-108 Oxford.

Hedges, R.E.M., 2003. On bone collagen - apatite-carbonate isotopic relationships. Int. J. Osteoarchaeol. 13, 66-79. http://dx.doi.org/10. 1002/oa.660.

Hedges, R.E.M., Reynard, L.M., 2007. Nitrogen isotopes and the trophic level of humans in archaeology. J. Archaeol. Sci. 34, 1240-1251. http://dx.doi.org/10.1016/j.jas.2006.10.015.

Hollund, H.I., Ariese, F., Fernandes, R., Jans, M.M.E., Kars, H., 2013. Testing an alternative high-throughput tool for investigating bone diagenesis: FTIR in Attenuated Total Reflection (ATR) Mode*. Archaeometry 55 (3), 507-532. http://dx.doi.org/10.1111/j.14754754.2012.00695.x.

Howland, M.R., Corr, L.T., Young, S.M.M., Jones, V., Jim, S., van der Merwe, N.J., Mitchell, A.D., Evershed, R.P., 2003. Expression of the dietary isotope signal in the compound-specific $\delta^{13} \mathrm{C}$ values of pig bone lipids and amino acids. Int. J. Osteoarchaeol. 13, 54-65. http://dx.doi.org/10.1002/oa.658.

Jørkov, M.L.S., Jørgensen, L., Lynneruo, N., 2010. Uniform diet in a diverse society. Revealing new dietary evidence of the Danish Roman Iron Age based on stable isotope analysis. Am. J. Phys. Anthropol. 143, 523-533. http://dx.doi.org/10.1002/ajpa.21346.

Keenleyside, A., Schwarcz, H., Stirling, L., Lazreg, N.B., 2009. Stable isotopic evidence for diet in a Roman and Late Roman population from Leptiminus, Tunisia. J. Archaeol. Sci. 36, 51-63. http://dx.doi.org/ 10.1016/j.jas.2008.07.008.

Killgrove, K., Tykot, R.H., 2013. Food for Rome: a stable isotope investigation of diet in the Imperial period ( $1 \mathrm{st}-3 \mathrm{rd}$ centuries AD). J. Anthropol. Archaeol. 32, 28-38. http://dx.doi.org/10.1016/j.jaa.2012.08.002.

King, A., 1999. Diet in the Roman world: a regional inter-site comparison of the mammal bones. Journal of Roman Archaeology 12, 168-202. http://dx.doi.org/10.1017/S1047759400017979.

Knipper, C., Peters, D., Meyer, C., Maurer, A.-F., Muhl, A., Schöne, B.R., Alt, K.W., 2012. Dietary reconstruction in Migration Period Central Germany: a carbon and nitrogen isotope study. Archaeol. Anthropol. Sci. 5 (1), 17-35. http://dx.doi.org/10.1007/s12520-012-0106-3.

Koch, P.L., Tuross, N., Fogel, M.L., 1997. The effects of sample treatment and diagenesis on the isotopic integrity of carbonate in biogenic hydroxylapatite. J. Archaeol. Sci. 24, 417-429. http://dx.doi.org/10. 1006/jasc.1996.0126.

Lebon, M., Reiche, I., Bahain, J.-J., Chadefaux, C., Moigne, A.-M., Fröhlich, F., Sémah, F., Schwarcz, H.P., Falguères, C., 2010. New parameters for the characterization of diagenetic alterations and heat-induced changes of fossil bone mineral using Fourier transform infrared spectrometry. J. Archaeol. Sci. 37, 2265-2276. http://dx.doi.org/10. 1016/j.jas.2010.03.024.

Lee-Thorp, J.A., 2008. On isotopes and old bones*. Archaeometry 50 (6), 925-950. http://dx.doi.org/10.1111/j.1475-4754.2008.00441.x

Longin, R., 1971. New method of collagen extraction for radiocarbon dating. Nature 230, 241-242. http://dx.doi.org/10.1038/230241a0.

Longinelli, A., 1984. Oxygen isotopes in mammal bone phosphate: a new tool for paleohydrological and paleoclimatological research? Geochim. Cosmochim. Ac. 48, 385-390. http://dx.doi.org/10.1016/ 0016-7037(84)90259-X.

Lopes, M.C., Alfenim, R., 1994. . A villa romana do Monte da Cegonha. Arqueologia en el terno del Bajo Guadiana. pp. 485-502.

Lovejoy, C.O., Meindl, R.S., Pryzbeck, T.R., Mensforth, R.P., 1985. Chronological metamorphosis of the auricular surface of the ilium: a new method for the determination of a adult skeletal age at death. Am. J. Phys. Anthropol. 68 (1), 15-28. http://dx.doi.org/10.1002/ajpa. 1330680103.

Lukacs, J.R., 1989. Dental paleopathology: methods for reconstructing health status and dietary patterns in prehistory. In: Iscan, M.Y., Kennedy, K.A.R. (Eds.), Reconstruction of Life from the Skeleton. Alan R. Liss Inc., New York, pp. 261-286.

MacKinnon, M., 1999-2000. O papel dos animais na economia rural da Lusitânia romana: zooarqueologia de Torre de Palma. A Cidade Revista Cultural de Portalegre 13-14, 129-140.
MacLaughlin, S.M., 1990. Epiphyseal fusion at the sternal end of the clavicle in a modern portuguese skeletal sample. Antropologia Portuguesa 8, 59-68.

Maurer, A.-F., Gerard, M., Person, A., Barrientos, I., del Carmen Ruiz, P., Darras, V., Durlet, C., Zeitoun, V., Renard, M., Faugère, B., 2011. Intra-skeletal variability in trace elemental content of Precolumbian Chupicuaro human bones: the record of post-mortem alteration and a tool for palaeodietary reconstruction. J. Archaeol. Sci. 38, 1784-1797. http://dx.doi.org/10.1016/j.jas.2011.03.008.

Maurer, A.-F., Galer, S.J.G., Knipper, C., Beierlein, L., Nunn, E.V., Peters, D., Tütken, T., Alt, K.W., Schöne, B.R., 2012. Bioavailable ${ }^{87} \mathrm{Sr} /{ }^{86} \mathrm{Sr}$ in different environmental samples - effects of anthropogenic contamination and implications for isoscapes in past migration studies. Sci. Total Environ. 433, 216-229. http://dx.doi.org/10.1016/j.scitotenv. 2012.06.046.

Maurer, A.-F., Person, A., Tütken, T., Amblard-Pison, S., Ségalen, L., 2014. Bone diagenesis in arid environments: an intra-skeletal approach. Palaeogeogr. Palaeoclimatol. Palaeoecol. 416, 17-29. http://dx.doi. org/10.1016/j.palaeo.2014.08.020.

Mays, S., Beavan, N., 2012. An investigation of diet in early Anglo-Saxon England using carbon and nitrogen stable isotope analysis of human bone collagen. J. Archaeol. Sci. 39, 867-874. http://dx.doi.org/10. 1016/j.jas.2011.10.013.

Mendonça, M.C., 2000. Estimation of height from the lenght of long bones in a Portuguese adult population. Am. J. Phys. Anthropol. 112 (1), 39-48. http://dx.doi.org/10.1002/(SICI)10968644(200005)112:1<39::AID-AJPA5>3.0.CO;2-\#.

Moore, W.J., Corbett, M.E., 1971. The distribution of dental caries in ancient British populations. 1. Anglo-Saxon period. Caries Res. 5 (2), 151-168.

Moreno-Larrazabal, A., Teira-Brión, A., Sopelana-Salcedo, I., AranzOtaegui, A., Zapata, L., 2015. Ethnobotany of millet cultivation in the north of the Iberian Peninsula. Veg. Hist. Archaeobot. 24 (4), 541-554. http://dx.doi.org/10.1007/s00334-015-0518-y.

Müldner, G., Richards, M.P., 2007. Stable isotope evidence for 1500 years of human diet at the City of York, UK. Am. J. Phys. Anthropol. 133, 682-697. http://dx.doi.org/10.1002/ajpa.20561.

Müldner, G., Chenery, C., Eckardt, H., 2011. The 'Headless Romans': multi-isotope investigations of an unusual burial ground from Roman Britain. J. Archaeol. Sci. 38, 280-290. http://dx.doi.org/10. 1016/j.jas.2010.09.003.

München, G.M., 2007. Using ${ }^{13} \mathrm{C}-,{ }^{15} \mathrm{~N}$ - and ${ }^{18} \mathrm{O}$ Stable Isotope Analysis of Human Bone Tissue to Identify Transhumance, High Altitude Habitation and Reconstruct Palaeodiet for the Early Medieval Alpine Population at Volders, Austria (Dissertation) University of Munich.

Nielsen-Marsh, C.M., Hedges, R.E.M., 2000. Patterns of diagenesis in bone I: the effects of site environments. J. Archaeol. Sci. 27, 1139-1150. http://dx.doi.org/10.1006/jasc.1999.0537.

Payne, S., 1973. Kill-off Patterns in Sheep and Goats: the Mandibles From Asvan Kale. The British Institute at Ankara, pp. 281-303 http://dx.doi.org/10.2307/3642547 (23).

Person, A., Bocherens, H., Saliège, J.-F., Paris, F., Zeitoun, V., Gérard, M., 1995. Early diagenetic evolution of bone phosphate: an X-ray diffractometry analysis. J. Archaeol. Sci. 22, 211-221. http://dx.doi. org/10.1006/jasc.1995.0023.

Person, A., Bocherens, H., Mariotti, A., Renard, M., 1996. Diagenetic evolution and experimental heating of bone phosphate. Palaeogeogr. Palaeoclimatol. Palaeoecol. 126, 135-149. http://dx.doi.org/10. 1016/S0031-0182(97)88906-7.

Pollard, A.M., Ditchfield, P., McCullagh, J.S.O., Allen, T.G., Gibson, M., Boston, C., Clough, S., Marquez-Grant, N., Nicholson, R.A., 2011. "These boots were made for walking": the isotopic analysis of a $C_{4}$ Roman inhumation from Gravesend, Kent, UK. Am. J. Phys. Anthropol. 146, 446-456. http://dx.doi.org/10.1002/ajpa.21602.

Prowse, T., Schwarcz, H.P., Saunders, S., Macchiarelli, R., Bondioli, L., 2004. Isotopic paleodiet studies of skeletons from the Imperial Roman-age cemetery of Isola Sacra, Rome, Italy. J. Archaeol. Sci. 31, 259-272. http://dx.doi.org/10.1016/j.jas.2003.08.008. 
Prowse, T.L., Schwarcz, H.P., Saunders, S.R., Macchiarelli, R., Bondioli, L., 2005. Isotopic evidence for age-related variation in diet from Isola Sacra, Italy. Am. J. Phys. Anthropol. 128, 2-13. http://dx.doi.org/10. 1002/ajpa.20094.

Rand, A.J., 2011. Ancient Maya Diet at Caledonia, Cayo District, Belize: The Isotopic Evidence (Dissertation) Trent University.

Richards, M.P., Mays, S., Fuller, B.T., 2002. Stable carbon and nitrogen isotope values of bone and teeth reflect weaning age at the Medieval Wharram Percy site, Yorkshire, UK. Am. J. Phys. Anthropol. 119, 205-210. http://dx.doi.org/10.1002/ajpa.10124.

Rutgers, L.V., van Strydonck, M., Boudin, M., van der Linde, C., 2009. Stable isotope data from the early Christian catacombs of ancient Rome: new insights into the dietary habits of Rome's early Christians. J. Archaeol. Sci. 36, 1127-1134. http://dx.doi.org/10.1016/j. jas.2008.12.015.

Salesse, K., Dufour, E., Castex, D., Velemínský, P., Santos, F., Kuchařová, H., Jun, L., Brǔžek, J., 2013. Life history of the individuals buried in the St. Benedict Cemetery (Prague, 15th-18th centuries): insights from ${ }^{14} \mathrm{C}$ dating and stable isotope $\left(\delta^{13} \mathrm{C}, \delta^{15} \mathrm{~N}, \delta^{18} \mathrm{O}\right)$ analysis. Am. J. Phys. Anthropol. 151, 202-214. http://dx.doi.org/10.1002/ajpa. 22267.

Salesse, K., Dufour, E., Lebon, M., Wurster, C., Castex, D., Bruzek, J., Zazzo, A., 2014. Variability of bone preservation in a confined environment: the case of the catacomb of Sts Peter and Marcellinus (Rome, Italy). Palaeogeogr. Palaeoclimatol. Palaeoecol. 416, 43-54. http://dx.doi.org/10.1016/j.palaeo.2014.07.021.

Scheuer, L., Black, S., 2004. The Juvenile Skeleton. Academic Press, Amsterdam.

Schoeninger, M.J., DeNiro, M.J., 1984. Nitrogen and carbon isotopic composition of bone collagen from marine and terrestrial animals. Geochim. Cosmochim. Ac. 48, 625-639. http://dx.doi.org/10.1016/ 0016-7037(84)90091-7.

Schoeninger, M.J., Moore, K., 1992. Bone stable isotope studies in archaeology. J. World Prehist. 6 (2), 247-296. http://dx.doi.org/10. 1007/BF00975551.

Silva, A.M., 1995. Sex assessment using the calcaneus and talus. Antropologia Portuguesa 13, 107-119.

Silver, I.A., 1969. The ageing of domestic animals. In: Brothwell, D.R., Higgs, E.S. (Eds.), Science in Archaeology: A Comprehensive Survey of Progress and Research. Basic Books, pp. 283-302.

Smith, B.H., 1984. Patterns of molar wear in hunter-gatheres and agriculturalists. Am. J. Phys. Anthropol. 63, 39-84. http://dx.doi.org/10. 1002/ajpa.1330630107.

Sponheimer, M., Cerling, T.E., 2014. Investigating ancient diets using stable isotopes in bioapatites. In: Holland, H.D., Turekian, K.K. (Eds.), Treatise on Geochemistry. Elsevier Ltd, Amsterdam, pp. 341-355.

Stevens, R.E., Lightfoot, E., Allen, T., Hedges, R.E.M., 2012. Palaeodiet at Eton College Rowing Course, Buckinghamshire: isotopic changes in human diet in the Neolithic, Bronze Age, Iron Age and Roman periods throughout the British Isles. Archaeol. Anthropol. Sci. 4, 167-184. http://dx.doi.org/10.1007/s12520-012-0089-0.

Stokes, H.R., Müldner, G., Jenkins, E., 2011. An investigation into the archaeological application of carbon stable isotope analysis used to establish crop water availability: solutions and ways forward. In: Mithen, S., Black, E. (Eds.), Water, Life and Civilisation: Climate, Environment and Society in the Jordan Valley. Cambridge University Press, pp. 373-380.
Tafuri, M.A., Craig, O.E., Canci, A., 2009. Stable isotope evidence for the consumption of millet and other plants in Bronze Age Italy. Am. J. Phys. Anthropol. 139, 146-153. http://dx.doi.org/10.1002/ajpa. 20955.

Tereso, J.P.V., 2007. Paleoetnobotânica do povoado romano da Terronha de Pinhovelo (NE transmontano) (Dissertation) University of Porto.

Trueman, C.N., Privat, K., Field, J., 2008. Why do crystallinity values fail to predict the extent of diagenetic alteration of bone mineral? Palaeogeogr. Palaeoclimatol. Palaeoecol. 266, 160-167. http://dx. doi.org/10.1016/j.palaeo.2008.03.038.

Turner, B.L., Zuckerman, M.K., Garofalo, E.M., Wilson, A., Kamenov, G.D., Hunt, D.R., Amgalantugs, T., Frohlich, B., 2012. Diet and death in times of war: isotopic and osteological analysis of mummified human remains from southern Mongolia. J. Archaeol. Sci. 39, 3125-3140. http://dx.doi.org/10.1016/j.jas.2012.04.053.

Valente, M.J., Carvalho, A.F., 2014. Zooarchaeology in the Neolithic and Chalcolithic of Southern Portugal. Environ. Archaeol. 19 (3), 226-240. http://dx.doi.org/10.1179/1749631414Y.0000000022.

van Klinken, G.J., 1999. Bone collagen quality indicators for palaeodietary and radiocarbon measurements. J. Archaeol. Sci. 26, 687-695. http://dx.doi.org/10.1006/jasc.1998.0385.

van Klinken, G.J., Richards, M.P., Hedges, B.E.M., 2000. An overview of causes for stable isotopic variations in past european human populations: environmental, ecophysiological, and cultural effects. In: Ambrose, S.H., Katzenberg, M.A. (Eds.), Biogeochemical Approaches to Palaeodietary Analysis. Kluwer Academic/Plenum Publishers, pp. 39-63.

Vika, E., 2011. Diachronic dietary reconstructions in ancient Thebes, Greece: results from stable isotope analyses. J. Archaeol. Sci. 38, 1157-1163. http://dx.doi.org/10.1016/j.jas.2010.12.019.

von den Driesch, A., 1976. A guide to the measurement of animal bones from archaeological sites. Peabody Museum Bulletins vol. 1. Peabody Museum Press.

Wasterlain, R.S.N., 2000. Morphé: análise das proporções entre os membros, dimorfismo sexual e estatura de uma amostra da Colecção de Esqueletos Identificados do Museu Antropológico da Universidade de Coimbra (Dissertation) University of Coimbra.

Weiner, S., Bar-Yosef, O., 1990. States of preservation of bones from prehistoric sites in the near east: a survey. J. Archaeol. Sci. 17, 187-196. http://dx.doi.org/10.1016/0305-4403(90)90058-D.

Wright, L.E., Schwarcz, H.P., 1996. Infrared and isotopic evidence for diagenesis of bone apatite at Dos Pilas, Guatemala: palaeodietary implications. J. Archaeol. Sci. 23, 933-944. http://dx.doi.org/10. 1006/jasc.1996.0087.

Zeder, M.A., 2006. Reconciling rates of long-bone fusion and tooth eruption and wear in sheep (Ovis) and goat (Capra). In: Wilson, B., Payne, S., Grigson, C. (Eds.), Ageing and Sexing Animals from Archaeological Site. British Archaeological Reports, Oxford, pp. 87-118.

Zeder, M.A., Lapham, H.A., 2010. Assessing the reliability of criteria used to identify postcranial bones in sheep, Ovis, and goats, Capra. J. Archaeol. Sci. 37 (11), 2887-2905. http://dx.doi.org/10.1016/j.jas. 2010.06.032.

Zeder, M.A., Pilaar, S.E., 2010. Assessing the reliability of criteria used to identify mandibles and mandibular teeth in sheep, Ovis, and goats, Capra. J. Archaeol. Sci. 37 (2), 225-242. http://dx.doi.org/10.1016/j. jas.2009.10.002. 